\title{
Domicile Under Immigration and Nationality Act Section 212(c): Escaping the Chevron "Trap" of Agency Deference
}

\author{
Kerne H.O. Matsubara $\uparrow$
}

Historically, noncitizens convicted of certain crimes have been barred from entering the United States, or have been deported for the commission of such crimes while in the United States. Section 212(c) of the Immigration and Nationality Act of 1952, however, gives the Attorney General the authority to grant a discretionary waiver to noncitizens excluded or deported due to criminal convictions. One requirement that must be met before a discretionary waiver may be granted is that an alien must have had a lawful, unrelinquished domicile for seven consecutive years. The application of this domicile requirement in deportation cases has been the subject of controversy and confusion. A circuit split has developed over how the period of domicile should be measured: some circuits deferring to the Board of Immigration Appeals (BIA) position that an alien cannot continue to accrue domicile years once a deportation order is "administratively final," and others holding that domicile years are accrued until an alien has exhausted court of appeals review. This Comment evaluates the BLA's administratively final approach and the deference standard of review applied by the courts that have adopted that approach. The author argues that judicial deference is inappropriate for agency rules where, as with the administratively final rule, the agency is interpreting the scope of its own authority under a statute that has been subject to extensive judicial and administrative tinkering. Rather, in such cases, courts should review agency determinations unconstrained by a deference standard. Moreover, the author argues that a clear definition of 212(c)'s requirements is necessary to carry out Congress' intent to give relief to rehabilitated criminals, and to eliminate the circuit split over domicile accrual, thus promoting the goal of nationally uniform application of immigration laws. Finally, the author proposes that the proper definition of 212(c)'s domicile requirement

Copyright @ 1994 California Law Review, Inc.

$\dagger$ A.B. 1986, Brown University; M.A. 1987 Stanford University; J.D. candidate 1995, Boalt Hall School of Law, University of California, Berkeley. I would like to thank Professor Daniel Rodriguez for his invaluable assistance and guidance. I also thank my cditors, Tung Yin and Aishah Smith, for their insights and suggestions. 
includes accrual of domicile time until an alien's deportation order is judicially final, defined as that time at which the time to file for judicial review of a deportation order is expired, or when a federal appeals court denies a petition for reversal of a deportation order.

\section{INTRODUCTION}

"California Leads Anti-Immigrant Wave," "Politicians Paying Attention to Uproar Over Immigration," and "Grass-Roots Anger Takes Hold," scream the headlines. ${ }^{1}$ These headlines are not those of United States immigration's early 20th-century heyday, but they are the news-grabbing stories of 1994. The steady increase in the numbers of new immigrants to the United States during the 1980s, coupled with an econonic recession in the 1990 s, has aroused popular anti-immigrant sentinent to an almost feverish pitch. In this current clinuate of immigrant hostility, nuore than 100 immigration-control bills lie pending before Congress in $1994 .^{2}$

Congress has already taken aim at one of the easiest targets: criminally convicted immigrants. In October 1990 Congress passed the Immigration Act of $1990,{ }^{3}$ the nuost conprehensive immigration reform since 1952. ${ }^{4}$ The 1990 Act reformed the immigration systen and in the process tougliened the restrictions on criminal aliens, who were among the liardest hit. 5 The Act targeted criminal aliens by broadening the class of crines for which an alien nay be excluded fronı entermg or be deported fronı tlie United States. ${ }^{6}$

Congress historically has excluded noncitizens convicted of certain criminal offenses fron1 entering the United States and has deported aliens convicted of committing sucl crimes in the United States. ${ }^{7}$ Section 212 (c) of the 1952 Immigration and Nationality Act, ${ }^{8}$ however, authorizes the

1. Pamela Burdman, Grass-Roots Anger Takes Hold, S.F. ChroN., Mar. 30, 1994, at Al; Marc Sandalow, Politicians Paying Attention to Uproar over Immigration, S.F. ChroN., Mar. 31, 1994, at Al; Suzanne E. Solis, California Leads Anti-Immigrant Wave, S.F. CHron., Mar. 29, 1994, at A1.

2. Solis, supra note 1 , at $\mathbf{A 7}$.

3. Immigration Act of 1990, Pub. L. No. 101-649, 104 Stat. 4978 (codified as amended in scattered sections of 8 U.S.C.).

4. Austin T. Fragomen, JR. \& Steven C. Beli, immigration Fundamentals 1-12 (1992).

5. Id. at 1-1 to 1-3; 3 Charles Gordon \& Stanley MaILMan, ImMigration Law and Procedure § 74.0[2], at 74-6 (rev. ed. Supp. 1993); Jo Anne Adlerstein, Removing the Welcome Mat, THE RECORDER, May 21, 1991, at 8.

6. 8 U.S.C. $\$ 1182$ (a) (1988).

7. Act of March 3, 1875, ch. 141, 18 Stat. 477. This 1875 federal law was the first to restrict immigration by excluding non-citizens who were "convicts" or "prostitutes." Id.; see also DAvID Cariner et al., The Rights of Alifens and Refugees 55 (2d ed. 1990). The enumerated grounds for deportation and exclusion steadily grew over the years to include such crimcs as drug trafficking, commercialized vice, and crimes of "moral turpitude." See 8 U.S.C. $\$ 1182$ (a) (1988) (identifying the classes of exeludable aliens).

8. Immigration and Nationality Act of 1952, ch. 477, 66 Stat. 163 (1952) (codificd as amended at 8 U.S.C. $\S \S 1101-1503$ ) [hercinafter "Act"]. Section 212(c) of the Act is codified at 8 U.S.C. $\S 1182$ (c) (1988). 
Attorney General to grant a discretionary waiver to those aliens seeking reentry into this country.

Although section 212(c) expressly applies only to excludable returning aliens, the Second Circuit in Francis $v$. INS $S^{9}$ extended this waiver to deportable aliens whose offenses were excludable ones as well. ${ }^{10}$ The Immigration and Naturalization Service ("INS") later adopted this interpretation even for cases outside the Second Circuit. ${ }^{11}$ Section 212(c) now protects "excludees" and deportees alike, nationwide.

Despite its liberal reading of $212(\mathrm{c})$ in this one instance, the INS has consistently adopted a narrow interpretation of each of 212(c)'s requireinents to limit the number of aliens qualifying for deportation relief. ${ }^{12}$ One of 212(c)'s requirements is that an alien inust have had a lawful unrelinquished domicile in the United States for seven consecutive years to be eligible for relief. This domicile requireinent has caused inuch controversy and confusion. For example, when does domicile end for 212(c) purposes? What constitutes "lawful domicile"? Can an alien apply the time during deportation proceedings toward the seven-year domicile requireinent?

The Board of Immigration Appeals ("BIA"), which reviews INS decisions administratively, has ruled that an alien cannot continue to accrue domicile years once the Board affirms a deportation order, at which point the deportation becomes "administratively final."13 That is, an eligible 212(c) alien must have accumulated seven years of domicile before an administratively final deportation order is issued. Several circuits have affirmed this ruling in deference to the BIA and to the $\mathrm{INS}^{14}$ citing Chevron U.S.A. Inc. v. Natural Resources Defense Council, Inc. ${ }^{15}$ Chevron

9. 532 F.2d 268 (2d Cir. 1976).

10. Id. at 273. Exclusion is the process by which the INS denies admission to aliens seeking to enter the United States. Deportation is the process of removing aliens no longer permitted to remain in this country. Though overlapping, the grounds for exclusion are enumerated in 8 U.S.C. § 1182(a), while the grounds for deportation are listed in 8 U.S.C. $\S 1251$ (a).

The court held the Equal Protection Clause of the Fourteenth Amendment demands that excludable and deportable aliens receive equal treatment because there is no functional difference between an alien in the United States seeking to remain and an alien seeking to return from temporary travel abroad. Francis, 532 F.2d at 273; see also Tapia-Acuna v. INS, 640 F.2d 223, 225 (9th Cir. 1981).

11. In re Silva, 16 I. \& N. Dec. 26, 28-30 (BIA 1976) (adopting Francis).

12. The INS' contradictory approach can perhaps be attributed to its pereeption that other circuits would adopt Francis' rationale, and that the INS therefore had to adopt that position itself.

13. In re Lok, 18 I. \& N. Dec. 10I, 105 (BIA 1981). The INS and the BIA are separate entities. Although the statute grants discretionary authority to the Attomey General ("AG"), the AG does not personally consider each application. The AG delegates this authority to the INS' immigration judges, and delegates her immigration review authority to the BIA, which is responsible for reviewing the decisions made by the INS' immigration judges. See GoRDON \& MAILMAN, supra note 5, § 74.01[3][c], at 74-9; Mark A. Hall, Comment, Lawful Domicile Under Section 212(c) of the Immigration and Nationality Act, 47 U. CHI. L. Rev. 771, 776 n.25 (1980).

14. See, e.g., Jaramillo v. INS, I F.3d 1149, 1155 (11th Cir. 1993). See generally Variamparambil v. INS, 831 F.2d 1362, 1366 (7th Cir. 1987); Rivera v. INS, 810 F.2d 540, 540 (5th Cir. 1987).

15. 467 U.S. 837 (1984). 
is a landmark case in modern administrative law $\mathrm{m}$ which the United States Supreme Court held that when congressional statutes are ambiguous, courts should defer to the administrative agency's reasonable interpretations of the statute. ${ }^{16}$ Other appellate courts have disagreed, holding that domicile terminates as early as the date when the INS commences deportation proceedings (when the INS issues an order to show cause) ${ }^{17}$ or as late as when aliens have finally exhausted their court of appeals review. ${ }^{18}$

This Comment seeks to evaluate the approach adopted by the administrative agency and some courts to 212(c) relief and to provide an appropriate interpretation of section 212(c)'s seven-year domicile requireinent. Specifically, this Comment criticizes the BIA's administratively final interpretation of 212(c)'s domicile requirement and questions the courts' application of Chevron in upholding this interpretation. Courts should not defer to the agency when the agency imterprets the scope of its own authority, as the BIA does with 212(c) in determining 212(c) eligibility for aliens. ${ }^{19}$ If courts decide that the BIA's interpretation should be evaluated under Chevron, then the courts should not so cursorily apply the Chevron analysis to find in favor of BIA deference.

A clear definition of 212(c) - and one consistent with Congress' intent - is necessary for policy reasons. First, section 212(c) should apply to those rehabilitated criminal aliens who deserve such relief. My criticisin of the BIA's 212(c) interpretation is not tantamount to supporting the right of hardened criminal aliens to remain $\mathrm{m}$ the United States. Only the reformed convict stands to benefit from any potential easing of 212(c)'s eligibility requirements; those who cannot demonstrate rehabilitation will fail in 212(c)'s discretionary phase. With the deportation of criminal aliens

16. Id. at 842-44.

17. Marti-Xiques v. INS, 741 F.2d 350, 355 (11th Cir. 1984). The Eleventh Circuit has since joined the Fifth and Seventh Circuits' administratively final interpretation. Jaramillo, 1 F.3d at 1155 .

18. Butros v. INS, 990 F.2d 1142, 1145 (9th Cir. 1993). In Butros, the Ninth Circuit departed from the Fifth and Seventh Circuits' administratively final interpretation, which it previously adopted in Gonzales v. INS, 921 F.2d 236, 238 (9th Cir. 1990). Butros, 990 F.2d at 1145.

19. The BIA facially appears to be determining the scope of the INS', and not its own, authority to grant 212(c) rehef. However, the BIA and the INS may be regarded as one agency hecause together they administer this nation's immigration laws. Congress grants to the Attorney Gencral discretionary authority to provide 212(c) rehief; neither the INS in approving 212(c) applications nor the BIA in interpreting when an alien is eligible for 212(c) relief may enlarge the scope of Congress' original grant of authority to the Attorney General. In this sense we should be concemed over the BIA's dctermining the scope of its "own" authority. See also infra text accompanying notes 176-78, 211-27.

Alternatively, both the BIA and the INS operate under the Attomey General's administrativc jurisdiction. See 28 C.F.R. $\S \S 0.1-.5$ (1994). Section 212(c) authorizcs the Attorney Gcneral to grant aliens discretionary relief, authority which the Attorney General, in turn, has delegated to the INS. See supra note 13. Perhaps more aecurately then, the Attorney General detcrmines the scope of her own authority by applying the administratively final rule adopted by one subordinate entity, the BIA, in deciding whether another subordinate entity, the INS, may act on an alien's 212(c) application. 
at an all-time high, ${ }^{20}$ section 212 (c) must serve as an effective safety valve to prevent the mass deportation of reformed aliens with criminal pasts. ${ }^{21}$

Second, section 212(c) should be interpreted uniformly to heal an intercircuit split. This circuit split has resulted in an uneven application of the immigration laws, which fairness demands should be nationally uniform. ${ }^{22}$ Currently, the Fifth Circuit's administratively final interpretation governs a 212(c) applicant in Texas, while the Ninth Circuit's ${ }^{23}$ "appeals court review" cutoff applies to an alien residing in Califorma and the Second Circuit's ${ }^{24}$ "motion to reopen" approach controls in New York. ${ }^{25}$

Part I of this Comment describes the origins and workings of section 212(c)'s deportation waiver. This background section discusses 212(c)'s legislative history, the INS' application of and the BIA's rulings on this waiver provision, and the federal appellate courts' varying interpretations of 212(c)'s domicile requirement. Part II criticizes the BIA's administratively final interpretation of 212(c) as being inconsistent with congressional intent and as agamst public policy. Part III argues that the federal courts, not the BIA, should interpret 212(c)'s domicile requirement. Federal appellate courts should not, in this instance, defer to the Agency's interpretation. Despite Chevron's principle of agency deference, the courts can resolve this question of law on their own, as part of their duty to resolve questions of law involving statutory construction. Part IV proposes the adoption of a "judicially final" rule which would allow aliens to accrue domicile during the pendency of federal court review of their deportation orders. This rule accords with Congress' intent in creating 212(c) and more effectively

20. Deportation of criminals averaged 876 per year during 1980-89. The annual average during 1990-91 was 2,355. See U.S. Dep't of Justice, 1991 Statistical. Yearbook of the Immigration and Naturatization Service 152, tbl. 61 (1992).

21. Section 212(c) should not, as the INS has, succumb to popular anti-immigrant fervor and political pressure. In response to the 1990 Immigration Act's crack-down on criminal aliens, the INS vigorously, but not always carefully, enforced the new immigration laws. These stepped-up efforts have occasionally resulted in overzealous deportations, including erroneous deportation of "foreign-looking" American citizens. Suzanne Espinoza, Born in U.S.A.-But Deported, S.F. CHroN., Oct. 22, 1993, at Al.

22. The Constitution charges Congress to "establisl a uniform rule of naturalization." U.S. CoNST. art. I, § 8, cl. 4. Moreover, federal preemption applies in the area of immigration to prevent the separate states from enacting laws which may affect immigration. See De Canas v. Bica, 424 U.S. 351, 354 (1976); Hines v. Davidowitz, 312 U.S. 52, $62-63$ (1941).

23. Butros v. INS, 990 F.2d 1142, 1145 (9th Cir. 1993) (allowing aliens' domicile to continue until they have exhausted their court of appeals review).

24. Vargas v. INS, 938 F.2d 358, 361-62 (2d Cir. 1991) (extending lawful domicile until aliens exhaust their legal and administrative remedies, including motions to the BIA to reopen or reconsider).

25. Despite the creation of the INS to apply and enforce the nation's immigration and naturalization laws uniformly, the federal courts of appeals control INS action in their respective jurisdictions. The BIA noted that

a principal mission of the Board of Immigration Appeals is to ensure as uniform an interpretation and application of this country's immigration laws as is possible. At times achieving this goal is beyond our control as our decisions are reviewable in federal court and we ordinarily apply the law of a circuit to the cases that arise within that circuit.

In re Cerna, Interim Dec. 3161, at 10 (BIA 1991). 
allows aliens to pursue other statutorily granted rights and to fulfill their obligations as residents of this country.

\section{BACKGROUND}

\section{A. Operation of Section 212(c)}

The case of In re Silva ${ }^{26}$ illustrates how section $212(\mathrm{c})^{27}$ operates. Silva was a Mexican native admitted to the United States as a permanent resident in 1954, when he was twelve years old. In 1974, Silva was convicted in a Texas federal district court of nuarijuana possession with the intent to distribute. Silva served six nionths of a five-year sentence. ${ }^{28}$ When the INS commenced deportation proceedings against Silva because of this drug offense, ${ }^{29}$ Silva conceded deportability at his hearing.

As part of the hearing procedures, Silva also filed an "Application for Advance Permission to Return to Unrelinquished Domicile,"30 212(c)'s waiver of deportation apphication. Despite the application's title, it nay also be used by permanent residents in deportation proceedings. Following the Second Circuit's Francis decision, the INS extended 212(c) relief to deportable permanent residents who had never left the country, when the basis for deportation was the same as one of the exclusion grounds for which a waiver was available. ${ }^{31}$ Because narijuana conviction is both an

26. 16 I. \& N. Dec. 26 (BIA 1976).

27. Section $212(\mathrm{c})$ reads in full:

Aliens lawfully admitted for permanent residence who temporarily procccded abroad voluntarily and not under an order of dcportation, and who are retuming to a lawful unrehinquished domicile of seven consecutive years, may be admitted in the discretion of the Attorney General without regard to the provisions of subsection (a) of this section (other than paragraphs (3) and $(9)(C)$ ). Nothing contained in this subsection shall limit the authority of the Attomey General to exercise the discretion vested in him under section 1181(b) of this title. The first sentence of this subsection shall not apply to an alien who has been convicted of one or more aggravated felonies and has served for such felony or felonics a term of imprisonment of at least 5 years.

8 U.S.C. $\$ 1182$ (c) (Supp. V 1993).

28. In re Silva, 16 I. \& N. Dec. at 26.

29. Under then applicable section 241(a)(11) of the Immigration and Nationality Act, aliens were deportable if, at any time after entry, they had been convieted of violating any law relating to the illicit possession of or traffic in narcotic drugs or marijuana. 8 U.S.C. $\S 1251$ (a)(11) (1988), amended by 8 U.S.C. $\S 1251$ (a)(2)(B) (Supp. V 1993).

30. In re Silva, 16 I. \& N. Dec. at 27. This application is also known as INS Form I-191. Form I191 asks the alien applicant's residence and employment during the past scven years, the location of immediate family members, and the reason why the ahen may not be readmitted to the United States following departure. See Bill O. HiNg, Handling ImMigration Cases 486-87 (1985).

31. See supra notes 9-11 and accompanying text. In 1976, the Sccond Circuit in Francis v. INS held that the disparate treatment of deportees and "excludees" violated equal protection, bccause "an alien whose ties with this country are so strong that he has never departed after his initial cntry should receive at least as much consideration as an individual who may lcave and return from time to time." Francis v. INS, 532 F.2d 268, 273 (2d Cir. 1976). Persuaded, albeit reluctantly, by this reasoning, the BIA adopted the Francis approach on a nationwide basis. See In re Silva, 16 I. \& N. Dec. 26 (BIA 1976); see also Vissian v. INS, 548 F.2d 325, $328 \mathrm{n} .3$ (10th Cir. 1977). For a discussion of Francis, see 2 AUSTIN T. FRAGOMEN, JR. ET AL., IMMIGRATION LAW AND BuSINESS $§ 6.4(a), 6-110$ to 6-114 (1994). 
excludable and deportable offense and is waivable under 212(c)'s exclusion rules, this offense is waivable during deportation proceedings as well.

The INS' district director may, as a matter of discretion, approve such waiver. ${ }^{32}$ If approved, the waiver permanently protects the alien from being excluded or deported on the grounds specified in the waiver. ${ }^{33}$ If the waiver is denied, an alien may not appeal to the district director for reconsideration, but may renew the application before an immigration judge ("IJ"). ${ }^{34}$ The IJ may also independently consider a 212(c) application in connection with deportation proceedings, regardless of whether the alien previously applied to the district director for a 212 (c) waiver. ${ }^{35}$

Section 212(c) rehief does not explicitly require that the applicant demonstrate "good moral character" or "extreme hardship"; lowever, the IJ will consider these important factors in deciding whether to grant a waiver. ${ }^{36}$ Although 212 (c) applications are discretionary and treated on a case-by-case basis, the BIA has established criteria for an equitable application of discretionary relief. Factors favorable to an applicant include family ties within the United States, long duration of residence in this country (particularly when the alien arrived in the United States at a young age), hardship to the applicant and family if deportation occurs, history of einployment, community or business ties, and good noral character (including criminal rehabilitation). ${ }^{37}$ Among the adverse factors are the underlying nature of the grounds for exclusion, the seriousness and recency of past crines, violation of other immigration laws, and bad character. ${ }^{38}$

The IJ judge found Silva deportable, denied his waiver application, and ordered his deportation to Mexico. ${ }^{39}$ When a 212 (c) request is denied, an alien inay appeal, as of right, the IJ's decision to the BIA. ${ }^{40}$ The grounds

32. U.S. Dep't of Justice, Immigration \& Naturalization Service, Operations INSTRUCTIONS, REGULATIONS, AND INTERPRETATIONS, \$ 212.3(a)-(b), at 874-874.1 (Rev. ed. 1952 \& 1994 Supp.) [hereinafter INS CoDEs].

33. In re G- A-, 7 I. \& N. Dec. 274, 275 (BLA 1956), modified on other grounds, In re Przygocki, 17 I. \& N. Dec. 361, 363-64 (BIA 1980).

34. INS CODES, supra note $32, \S 212.3(\mathrm{~d})$.

35. Upon filing a 212(c) application, the INS usually conducts a character investigation, which may last up to two or more years. HnNG, supra note 30 , at 307 . The IJ relies on this character investigation in addition to the testimony and affidavits of family members, friends, cmployers, parole officers, and psychiatrists. Id. After considering this evidence and weighing the favorable and unfavorable factors, the IJ issues a decision, setting forth the basis for the exercise of discretion, which is subject to administrative and judicial review. 3 GORDON \& MAIMAN, supra note 5, § 74.04[3][c], 7453.

36. Bill O. Hing \& Shari Crumlac, Wnnnng 212(c) Cases 1-2 (1990).

37. In re Marin, 16 I. \& N. Dec. 581, 584-85 (BIA 1978).

38. Id. at 584 .

39. In re Silva, 16 I. \& N. Dec. 26, 27 (BIA 1976). Had the IJ approved Silva's application, the deportation waiver for this offense would have been valid indefinitely throughout his stay in the United States. 8 C.F.R. $\$ 212.3$ (d) (1993); see INS CODES, supra note 32, at 874.1.

40. 8 C.F.R. $\$ \S 3.1(\mathrm{~b})(3), 242.21$ (a) (1993). The AG has authorized the INS to administer and enforce laws relating to the immigration and naturalization of aliens. However, as a last administrative recourse, aliens may appeal their orders of deportation to the BIA. See CARLINER ET AL., supra note 7, 
for appeal include questions of law, procedural questions, standards of evidence, and arbitrary exercise of discretion. ${ }^{41}$ Because the Board conducts de novo review, it need not defer to the IJ's findings on the alien's credibility and rehabilitation. ${ }^{42}$ If the BIA dismisses such an appeal and affirms the IJ's deportation order, the alien's deportation is considered administratively final. After the alien has exhausted these administrative remedies, an alien may seek review in the court of appeals within ninety days of the BIA's decision. ${ }^{43}$ A petition for review of a deportation order in a federal court of appeals automatically stays deportation until the court acts upon the petition. $^{44}$

\section{B. INS Application and BIA Interpretation of 212(c) 's Domicile Requirement}

Although Congress clearly specified the eligibility requirements of aliens seeking 212(c) exclusion waivers, that clarity has not extended to deportation cases. When applied to exclusion cases, domicile was measured by the length of the alien's stay im the United States before leaving this country. But how should "domicile" be imterpreted as applied to deportable aliens who seek 212(c) relief during their continued presence in the United States? The agencies and the federal courts disagree over how to interpret 212(c)'s requirements im light of Francis' extension of 212(c) relief to deportees. In particular, the Francis extension to deportees gave rise to a new controversy regarding the seven-year domicile requirement.

In In re Lok, the BIA determined that once a deportation order becomes administratively final, an alien's lawful permanent resident status terminates and domicile years may no longer accrue toward the seven-year requirement. ${ }^{45}$ An administratively final deportation order occurs either when the Board renders its decision in the case on appeal or when the alien fails to file a timely appeal to the Board. ${ }^{46}$ The Board reasoned that "[t]o hold that an alien under a final administrative order of deportation remains a lawful permanent resident throughout the judicial proceedings would

at 151; Janet M. Donovan, Comment, Immigration-Deportation-Limiting Aliens' Eligibility for $\$ 212$ (c) Relief from Deportation, Rivera v. INS, 810 F.2d 540 (5th Cir. 1987), 12 Surrolk TRANSNAT'L L.J. 219, 219 mn. 3, 5 (1988).

41. CARLINer ET AL., supra note 7, at 79, 151. See 8 U.S.C. $\$ 1226(\mathrm{~b})$ (1988) and 8 C.F.R. $\S 3.1$ (b) (1994) for regulations governing administrative appeals of INS decisions.

42. Ghassan v. INS, 972 F.2d 631, 635 (5th Cir. 1992), cert. denied, 113 S. Ct. 1412 (1993); Martinez v. INS, 970 F.2d 973, 974 (1st Cir. 1992).

43. 8 U.S.C. $\S 1105 a(a)$ (1) (Supp. V 1993). See Hivo, supra note 30, at 342. The Administrativc Procedure Act also provides for judieial review. 5 U.S.C. $\$ 702$ (1988). Congress provides that a "person suffering legal wrong because of agency action, or adversely affected or aggrieved by agency action ... is entitled to judicial review thereof." Id.

44. 8 U.S.C. $\S 1105$ (a)(3) (Supp. V 1993). See CarLINER et AL., supra note 7, at 151. As a last resort, a deportee may seek review of the INS' decision through a writ of habeas corpus in fedcral district court prior to departing the country. 8 U.S.C. $\S 1105 a(a)(10)$ (Supp. V 1993).

45. In re Lok, 18 1. \& N. Dec. 101, 105 (BIA 1981).

46. Id. 
encourage spurious appeals to the courts, made solely for the purpose of accumulating more time toward eligibility for section 212(c) relief."

Some courts, however, have taken a very different view. Since 1982, the courts of appeals decided no fewer than a dozen 212(c) cases in which the domicile requirement was at issue. ${ }^{48}$ The circuits have been unable to agree on the proper interpretation of 212(c) domicile, specifically the termination point of lawful domicile. As a result, the INS accords different treatment to 212(c) applicants depending on where the alien files for relief. This appellate court split involves circuits whose jurisdictions encompass states with high immigration populations: California, Florida, and New York. Following is a brief sketch of the circuits' 212(c) domicile decisions.

In Lok v. INS, ${ }^{49}$ the Second Circuit affirmed the BIA's ruling that Lok's lawful residence and domicile ended when his deportation became admimistratively final. Even though Lok remained in the United States subsequent to his final deportation order, this period of physical presence did not count toward the seven years. The court held that when Lok failed to appeal the BIA's decision within the allotted ten days, deportation became final and domicile ended. At this point, Lok "resided in the United States ... as a matter of grace, not law."50

Two other circuits, the Fifth and Seventh, reached similar results in Rivera v. INS, ${ }^{51}$ and in Variamparambil v. INS. ${ }^{52}$ The Rivera court affirmed the BIA's Lok rule on grounds that it was "not unreasonable" given the "great deference" accorded to the BIA..$^{53}$ The Variamparambil court reached the same result, citing Chevron's principle that the "INS' interpretation of $\S 212$ (c) is of course entitled to deference by [the court]." ${ }^{.54}$ In 1993, the Eleventh Circuit in Jaramillo v. INS ${ }^{55}$ abandoned its previous position and joined the Second, Fifth, and Seventh Circuits. ${ }^{56}$

47. Id. at 107.

48. See, e.g. Goncalves v. INS, 6 F.3d 830 (1st Cir. 1993); Jaramillo v. INS, 1 F.3d 1149 (11th Cir. 1993); Butros v. INS, 990 F.2d 1142 (9th Cir. 1993); Vargas v. INS, 938 F.2d 358 (2d Cir. 1991); Gonzales v. INS, 92I F.2d 236 (9th Cir. 1990); Variamparambil v. INS, 831 F.2d 1362 (7th Cir. 1987); Rivera v. INS, 810 F.2d 540 (5th Cir. 1987); Avila-Murrieta v. INS, 762 F.2d 733 (9th Cir. 1985); Reid v. INS, 756 F.2d 7 (3d Cir. 1985); Marti-Xiques v. INS, 741 F.2d 350 (11th Cir. 1984); Wall v. INS, 722 F.2d 1442 (9th Cir. 1984); Lok v. INS, 68I F.2d 107 (2d Cir. 1982).

49. 681 F.2d 107 (2d Cir. 1982).

50. Id. at 110 .

51. 810 F.2d 540 (5th Cir. 1987).

52. 831 F.2d 1362 (7th Cir. 1987).

53. Rivera, 810 F.2d at 540 .

54. Variamparambil, $831 \mathrm{~F} .2 \mathrm{~d}$ at 1366.

55. 1 F.3d 1149 (11th Cir, 1993).

56. Id. at 1155. In Marti-Xiques v. INS, 741 F.2d 350 (11th Cir. 1984), the Eleventh Circuit had adopted a position more extreme than that of the INS: permanent residence status terminated and domicile ended for 212(c) purposes when the INS issued an order to show cause. Id. at 355. Under this interpretation, an alien's ability to establish 212(c) domicile eligibility was summarily terminated as soon as deportation proceediugs commenced. An alien lost lawful 212(c) standing even before the opportunity for any hearing, immigration judge ruling, or appeal within the INS. This position was too extreme, even for the INS, which refused to adopt this ruhing in its own regulations and administrative 
In the Ninth Circuit, an ahien remains eligible for 212(c) relief "so long as the Board may reconsider or reopen the case."57 This interpretation negates the finality of the BIA's administratively final decision, giving a 212(c) applicant additional time to become eligible and to file for relief.

Returning full circle to the Second Circuit, whose Lok ruling initially affirmed the INS' administratively final rule, the rift among the circuits has widened. In 1991, the Second Circuit in Vargas v. INS 58 limited its Lok holding to the facts of that case. In Vargas, the court held that the BIA's decision to dismiss a notion to reopen because the petitioning alien failed to accrue seven years of domicile prior to an administratively final deportation order was arbitrary and capricious. ${ }^{59}$ The court linited its Lok holding only to situations where the aben has conceded deportability. Thus, a deportation order becomes administratively final not because the BIA says it is final, but because the alien fails to appeal timely the IJ's initial finding of deportability.

The current state of 212(c)'s domicile requirement is unsettled and still changing. One Ninth Circuit judge aptly describes the situation: "The INS continues to be pulled in all directions at once by fractious circuits. Maybe the Supreine Court will iron out all of these inpossible wrinkles, or maybe the INS will take this to Congress for repair. Time will tell."60 Nevertheless, the INS, the BIA, and a plurality of the circuits have adopted or affirmed the administratively final interpretation of 212(c) domicile.

decisions. Rivera, 810 F.2d at 542 n.1 (Williams, J., dissenting). Likewise, other courts have not followed Marti-Xiques. Id. In reversing Marti-Xiques, the Eleventh Circuit indicated that its prior holding was problematic and violated Chevron because it did "not pay sufficient heed to Supreme Court precedent which commands ns to defer to the interpretation of a statute by the agency charged with administering it, so long as the agency's interpretation is reasonable and is not inconsistent with the language of the statute or congressional intent." Jaramillo, 1 F.3d at 1152.

57. Butros v. INS, 990 F.2d 1142, 1145 (9th Cir. 1993). The Ninth Circuit has twice reversed itself to arrive at its current holding that the time accumulated while a deportation order is on appeal can effectively be counted towards the domicile requirement. In Wall v. INS, 722 F.2d 1442, 1444-45 (9th Cir. 1984), the Ninth Circuit departed from the Second Circuit's Lok ruling. Id. at 1444. The court held that the time to satisfy the seven-year domicile requirement could continue to accumulate after a final BIA decision directing deportation. However, in a move to align itself with the growing coalition of circuits, the Ninth Circuit in Gonzalez v. INS, 921 F.2d 236, 238 (9th Cir. 1990), adopted the Lok reasoning to render an alien inehibible for 212(c) relief upon a final BLA decision. This plurality was short-lived because in 1993 the Ninth Circuit reversed Gonzalez.

58. 938 F.2d 358 (2d Cir. 1991).

59. Id. at 361,363 .

60. Butros, 990 F.2d at 1153 (Trott, J., dissenting). 
II

The AgENCY's “AdMINISTRATIVEly Final” InTERPRETATION: The Fox Guarding the Hen House

This Part critiques the Agency's $\mathrm{s}^{61}$ interpretation of 212(c)'s seven-year domicile requireinent. The Agency's administratively final cutoff point for accruing seven years is an improper imterpretation of 212(c).$^{62}$ First, the Agency's interpretation is contrary to Congress' purpose in enacting the 212(c) waiver provision. Evaluated against the legislative history, the BIA's administratively final rule suffers from substantive and procedural defects. Second, this agency rule is also questionable on policy grounds where an enforcement measure as drastic as deportation is involved. Where Congress and the courts have recognized the severity of deportation by providing "safety valve" waivers, the Agency should resolve statutory ambiguities in the deportee's favor. The administratively final rule is a rule of administrative convenience that does little to honor the spirit of the statutory safety valves Congress accorded to aliens.

\section{A. Legislative History and Purpose}

There are two main sources from which to determine 212(c)'s legislative history and purpose: the Seventh Proviso to section 3 of the Immigration Act of 1917 and the congressional records surrounding 212(c)'s inclusion in the 1952 Immigration and Nationality Act. ${ }^{63}$ Whereas the Seventh Proviso provided the substantive reason for waiver provisions im United States immigration laws-that immigration laws be "humane"section 212(c) addressed procedural concerns over the AG's discretion to grant such waivers. The Agency's administratively final interpretation fails to adhere adequately to both the Seventh Proviso's substantive purpose and 212(c)'s procedural safeguards.

61. To clarify, the "agency" consists of two distinct entities-the INS and the BIA-each independent from the other. The AG delegates its discretionary authority to INS district directors and immigration judges, who consider whether to grant 212(c) waivers. See U.S. DEP'T of Justrce, Imamigration \& Naturalization Service, Deportation Officer's Handbook 73 (1981 \& Supp. 1986) [hereinafter Deportation OfFICER's HANDBOOK]. Only the BIA detcrmines the administratively final cutoff date by virtue of exhausting the alien's administrative remedies. Oftentimes aliens facing deportation appear before an IJ in a single hearing to determine concurrently whether the alien is deportable and whether relief should be granted. CARLINER ET AL., supra note 7, at 149. If the alien receives an unfavorable ruling on both counts, he or she may appeal to the BIA. See INS CoDEs, supra note $32, \S 212.3$ (d). At this point, the BIA has control over the timing of its administratively final decision and the authority to reverse the IJ's waiver denial.

62. The BIA formulated the administratively final rule in In re Lok, 18 I. \& N. Dec. 101, 105 (BIA 1981).

63. Immigration Act of 1917 , ch. 29, 39 Stat. 874, 875 (1917); Immigration \& Nationality Act of 1952 , ch. 477,66 Stat. 163 (1952) (codified as amended at 8 U.S.C. $\S \S 1101-1503$ ). 


\section{The Seventh Proviso: A Humane Provision}

When Congress enacted 212(c) as part of the 1952 Act, it continued, with modifications, the waiver provision granted under the Seventh Proviso. Because 212(c) is the Seventh Proviso reincarnated, it is proper to look at the purpose behind the Seventh Proviso to determine the fundamental reason for 212(c)'s existence.

Congress' basic reason for the Seventh Proviso was to ensure that the nation's immigration laws would not exclude from the United States aliens who deserved to renlain im this country. ${ }^{64}$ In particular, Congress attempted to ease the suffering which might result if a resident alien with strong ties to the United States were excluded or denied entry after a brief trip abroad. The Seventh Proviso's purpose was humane: to address the plight of aliens whose exclusion would result im "peculiar or unusual hardship."65

In the 1940s, the BIA embraced the humane notion of the Seventh Proviso. The Board wrote that there seemed to be "no doubt that Congress granted the discretion in the seventh proviso for the purpose of alleviating hardship." $" 66$ The Board further noted that "it would seem difficult, if not impossible, to sustain the view that an ahen who has resided in the United States for 7 years . . . must, ipso facto, be mcapable of suffering hardship."67 The Board siniply recognized the reality that an alien living in the Umited States for seven years would form strong economic or family ties to this country. ${ }^{68}$ Wrenching an ahen from these ties would violate the Seventh Proviso's humane intent.

At least one federal court of appeals also recognized that 212(c)'s legislative history reveals that Congress intended its waiver policy to be lenient and humane. In a 1992 opinion reversing the BIA's 212(c) interpretation of a minor alien's "domicile," the Second Circuit exammed 212(c) in light of the Seventh Proviso. ${ }^{69}$ The court noted that "it seenıs plain that Congress' policy, at least as regards waiver eligibility, is tolerant rather than strict, and accordingly does not envision barriers in addition to those already found in

64. Chapter 29, Section 3 of the 1917 Immigration Act identified the classes of aliens cxeluded from admission into the United States. The Seventh Proviso was the seventh of nine provisions to the exclusion rule. Immigration Act of 1917, ch. 29, 39 Stat. 874, 875-78 (1917).

65. S. REp. No. 352, 64th Cong., 1st Sess. 6 (1916); see also S. REp. No. 355, 63d Cong., 2d Sess. 6 (1914) (describing this discretionary waiver provision as "just and humane").

66. In re $\mathrm{H}-1$ I. \& N. Dec. 166, 168 (BIA 1941).

67. Id.

68. See, e.g., In re S-, 1 I. \& N. Dec. 376, 384 (BIA 1943).

The BIA, which was "primarily concemed with substantive rights and disabilities, not with form or procedure," extended Seventh Proviso relief to deportable aliens who left the United States intending later to return as immigrants. In re B-, 1 I. \& N. Dec. 204, 208 (BIA 1942). Permitting this "advance" exercise of the Seventh Proviso would "make possible a correction of immigration status in many worthy cases, and in such instances [would] not require deportation with its concomitants of economic and social distress to many American citizens, members of the families of the deportees." Id.

69. Rosario v. INS, 962 F.2d 220 (2d Cir. 1992). 
$\S 212(c) . "{ }^{30}$ Here the court identified the congressional tolerance expressed in the Seventh Proviso and leniently interpreted 212(c).

The Second Circuit also aptly described 212 (c) as a "humane provision," under which deportable aliens-even those with criminal pastsshould not be denied consideration. ${ }^{71}$ Congress surely did not intend 212(c) as blanket protective cover for hardened criminals desiring to remain in the United States only to commit further crimes. However, Congress at a minimum intended 212(c)'s beneficiaries to include those criminal aliens who could demonstrate rehabilitation in addition to deep family and economic roots in this country. Thus, in accordance with congressional intent, 212(c)'s eligibility requirements should not be so stringent as to exclude froin consideration those who have legitimate interests in remaining in this country and who have become law-abiding United States residents.

In contrast to this tolerant and humane view of 212(c), the Agency's administratively final interpretation serves merely to exclude those who otherwise are deserving of 212(c) relief. The Agency's interpretation falls short of the Seventh Proviso's humane purpose, because the agency rule is not designed to include all aliens who may successfully demonstrate unusual hardship. For exanuple, in determining whether an alien would suffer hardship, the BIA has looked to such factors as the alien's family ties within the United States, any employment history, and the existence of property or business ties. ${ }^{72}$ Resident aliens living in the Umited States for at least seven years almost inevitably form these ties. However, the Agency's administratively final rule does not allow all seven-year residents to apply for 212(c) relief. Specifically excluded from 212(c) consideration are lawfully admitted aliens who lave plyysically resided in this country for seven years ${ }^{73}$ and who have established significant ties to the United States, yet are subject to the misfortune of the BIA issuing its final deportation order prior to the end of the seven years. Thus, this agency rule is agency-based with little concern for the alien for whom waiver provisions were originally designed.

Another way in which the Agency violates the humane spirit of the waiver provision is by making the process more confusing to aliens. Although Congress' seven-year requirement is itself an arbitrary cutoff point, the Agency's administratively final rule adds a layer of technicality not envisioned by the statute. Indeed the primary function of a waiver provision is to extricate deserving aliens from the rigidities of the immigration

70. Id. at 223 (emphasis in original).

71. Lok v. INS, 548 F.2d 37, 39 (2d Cir. 1977). Lok had been convicted of possession and distrihution of a narcotic drug. See In re Lok, 15 I. \& N. Dec. 720, 720 (BIA 1976), remanded, Lok v. INS, 548 F.2d 37 (2d Cir. 1977).

72. In re Marin, 16 I. \& N. Dec. 581, 584-85 (BIA I978); see also supra notes 37-38 and accompanying text.

73. The seven years may include time aliens spend exercising their legal rights to administrative and judicial appcals. 
laws. Instead, the agency rule further entangles aliens in complex rules. Complexity arises when an alien's 212(c) eligibility depends on when the BIA determines that an alien's deportation is administratively final. An alien without seven years of domicile who loses a BIA deportation appeal simultaneously loses the ability to invoke section 212 (c), the very remedy available for deportation relief. Thus, the administratively final rule may put more than was intended at stake for the alien during a BIA appeal: administrative finality of deportation with a concomitant loss of a remedy.

\section{Section 212(c): Procedural Limits on Attorney General Discretion}

Although the Seventh Proviso established discretionary waivers, section 212(c) enacted a modified provision to limit the reach of the AG's discretion in granting waivers. The BIA, in adopting its admmistratively final rule, correctly cites to 212(c)'s legislative history; however, the BIA misconstrues the legislative history as supporting the notion that the Agency should interpret 212 (c) strictly. ${ }^{74}$

The BIA misunderstands 212 (c) as a provision primarily designed to minimize the number of aliens eligible for discretionary relief. Instead, the legislative history clearly shows that Congress created 212(c) eligibility requirements to limit, if not prevent, the agency from determining when it could or could not exercise its discretion. Section 212(c) makes clear that a two-part process is involved in granting discretionary waivers. A resident alien applicant must first satisfy congressionally established mimimum requirements; ouly then can the agency even consider exercising its discretion. Thus, 212(c)'s language addresses the process of giving out waivers, not necessarily who should get them.

The legislative discussions and reports surrounding 212(c) indicate that Congress was concerned over the AG (and the agency to which the AG would delegate this discretionary authority) having too inuch flexibility in determining whether an alien's waiver application should even be considered at all. Commentators supporting the BIA's administratively final rule properly characterize 212 (c) as a more restrictive version of its predecessor, the Seventh Proviso. ${ }^{75}$ However, while 212(c) is indeed inore restrictive, the question is whether Congress intended to apply these added restrictions to aliens seeking discretionary relief or to the AG's exercise of discretion. ${ }^{76}$ The legislative record suggests the latter.

74. In In re Lok, the BIA determined its administratively final rule was appropriate, opaquely referring to the "policies of the Act." 18 I. \& N. Dec. 101, 105 (BIA 1981). However, in In re Newton, the BIA contended that 212 (c)'s eligibility requirements were created to address prior lenient administrative decisions which expanded the Seventh Proviso's scope. 17 1. \& N. Dec. 133, 135-36 (BIA 1979).

75. See, e.g., Matthew A. Reiber, Comment, Section 2I2(c) of the Immigration and Nationality Act in the Federal Courts, 24 Colum. J. Transnat'z L. 623, 626 (1986).

76. Section $212(0)$ significantly restricted the discretionary power conferred on the $A G$ in two ways. First, $212(\mathrm{c})$ relief is available only to "[a]liens lawfully admitted for permanent residence." 
The Senate Judiciary Committee report on the proposed 1952 Immigration Act closely scrutinized the Seventh Proviso. ${ }^{77}$ In particular, the report focused on concerns that the Seventh Proviso gave the AG too much discretion, concerns so serious that some witnesses before the subcommittee recommended its abolishment. ${ }^{78}$ The Judiciary Committee noted that because the Seventh Proviso did not explicitly require waiver applicants to have been lawfully admitted into the United States, stowaways could use the Seventh Proviso to remain in the country. ${ }^{79}$ However, the Committee's concern was not merely over the stowaway's attenipt to use the Seventh Proviso to apply for a waiver, but rather over the AG's exercise of discretionary authority to grant the waiver. ${ }^{80}$

Similarly, the House report on the pending Immigration and Nationality bill discussed the nature of the AG's 212(c) discretionary authority. The House Judiciary Committee expressly cautioned that "any discretionary authority to waive the grounds for exclusion slould be carefully restricted to those cases where extenuating circumstances clearly require such action and that the discretionary authority should be surrounded with strict limitations." 1

Furthermore, the House rejected Representative Zablocki's proposed 212(c) amendment, which would have relaxed controls on the AG and restored the Seventh Proviso's language. Representative Zablocki offered to permit the AG to prescribe those conditions, in addition to the seven-year unrelinquished domicile requirement, under which discretion may be exercised. ${ }^{82}$ In stating his case, Representative Zablocki indicated that his amendment was intended to retain the broad discretion of the AG. ${ }^{83}$ To this Representative Walter replied that "it would be dangerous" to adopt this

Second, an alien's unrelinquished domicile of seven consecutive years must be "lawful." 8 U.S.C. 1182(c) (Supp. V 1993).

77. S. REP. No. 1515, 81st Cong., 2d. Sess. 381-84 (1950).

78. Id. at 383.

79. The report explained low a stowaway, who had previously been convicted of some crime involving "moral turpitude," could illegally enter the United States, reside in this country for seven years, acquire a family or property lere, cross the border into Canada, and apply for a Seventh Proviso waiver from an American consulate in Canada. Id.

80. The Subcommittee concluded that under this stowaway scenario, the "result is that the Attorney General may exercise his discretionary authority and authorize the admission of an alien notwithstanding the fact that there is a [criminal] conviction ... whicl would, ordinarily, preclude his lawful entry." Id.

81. H. ReP. No. 1365, 82d Cong., $2 d$ Sess. 51 (1952), reprinted in 1952 U.S.C.C.A.N. 1653, 1705 (empliasis added).

82. Similar to the Seventh Proviso, Rep. Zablocki's version of 212(c) would permit "[a]liens who temporarily proceeded abroad and not under an order of deportation, who are returning to an unrelinquished United States domicile of seven consecutive years, may be admitted in the discretion of the Attomey General, and under such conditions as he may describe." 98 Cong. Rec. H4434 (daily ed. Apr. 25, 1952) (statement of Rep. Zablocki). See Reiber, supra note 75, at 627, for an argument that the rejection of Zablocki's amendment more properly signals Congress' intent to limit 212(c) to only a narrow range of cases.

83. 98 Cong. Rec. H4434 (daily ed. Apr. 25, 1952) (statement of Rep. Zablocki). 
amendment. ${ }^{84}$ However, the danger to which Representative Walter referred was not hordes of aliens lining up to apply for 212(c) waivers, but the danger in conferring upon the AG such broad discretion. In short, congressional concern focused on when the AG could exercise discretion under 212(c) and not how this discretion should be exercised. ${ }^{85}$

In light of 212(c)'s legislative history indicating congressional fears of untrammeled AG discretion, the Agency's administratively final rule does not assuage such fears. Although on its face the rule seems to accord with 212(c)'s spirit of restricting the waiver provision, the rule actually gives the agency greater control in deciding when to exercise its discretionary authority. The administratively final rule is not inherently a strict limitation; it is strict or not depending upon how the agency chooses to apply it. Because the BIA itself determines when a deportation order is administratively final, the agency exerts significant control over one of 212(c)'s eligibility requirements.

Consider, for example, the case of George Variamparambil. ${ }^{86}$ Variamparambil was admitted to the United States as a lawful permanent resident on August 12, $1977 .{ }^{87} \mathrm{He}$ was convicted of a drug-related crime, charged by the INS with deportability, and he then petitioned for 212(c) relief. ${ }^{88}$ Despite the merits of his case, the agency rule made him ineligible for 212(c) relief, because the BIA issued a final order of deportation on August 1, 1984-eleven days shy of Variamparambil's seventh anniversary in the Umited States. ${ }^{89}$ The timing of the BIA's decision, which ultimately barred Variamparambil from seeking 212(c) relief, bore no relationship to the inerits of the case or to the fact that Variamparambil, notwithstanding the BIA's final order, eventually resided in this country for at least ten years. ${ }^{90}$

Under the administratively final rule, the BIA easily could have delayed its decision by a mere eleven days, accepted Variamparambil's 212(c) application, and granted discretionary relief. Thus, depending on how quickly the BIA chooses to finahize deportation orders, the Agency can decide which aliens can enter the 212(c) door. Once past this door, the INS operates with nearly untrammeled discretion. ${ }^{91}$ In the words of one review-

84. Id. (statement of Rep. Walter).

85. In the debate over section 212 (c) Congress did not consider replacing the AG's discretion with a statutorily defined list of factors identifying those aliens who should and should not be granted 212(c) relief. See supra notes 81-83.

86. Variamparambil v. INS, 831 F.2d 1362 (7th Cir. 1987).

87. Id. at 1363 .

88. Id.

89. Id. at 1366.

90. Until the Seventh Circuit Court of Appeals decided this case on October 15, 1987, Variamparambil remained in the United States pursuing legal remedies, including his rigbt to seek judicial review. Id. at 1363.

91. Section 212(c) grants broad discretionary authority; it does not instruct tbe agency which eligible $212(\mathrm{c})$ applicants should be granted or denied relief. The INS, bowever, 'is nonetheless 
ing court, the scope of review of the Agency's discretionary action then becomes "exceedingly narrow" because a lack of statutory standards provides the AG with "unusually broad" discretion." ${ }^{92}$ This is precisely the "danger" conteinplated im the legislative history.

\section{B. Deportation As a "Dreadful Punishment"}

Policy reasons also argue against the Agency's administratively final rule, whether or not dictated by congressional intent or legislative history. Judge Learned Hand once wrote: "[D]eportation is . . . a dreadful punishment, abandoned by the common consent of all civilized peoples."933 While Judge Hand inay have overstated the case, agency rules regarding deportation should be closely scrutinized because of the potentially devastating consequences of what amounts to banishment. ${ }^{94}$

There are two main policy reasons for striking down the Agency's rule. First, deportation rules deserve a "hard look," with any statutory ambiguities decided in the alien's favor. ${ }^{95}$ Where the alien's family attachments, property interests, and liveliliood are all at stake, deportation rules should err on the side of leniency. The Supreme Court has sanctioned this view of leniency in a number of decisions. ${ }^{96}$ Second, the Agency's rule conflicts with other statutory rights, which encourage, if not require, the alien's continued presence in the United States. Such rights include seeking judicial review upon exhaustion of administrative remedies, petitioning for an automatic stay of deportation, and pursuing a motion before the BIA to reopen or reconsider. Aliens slrould be allowed to accrue domicile time for time spent in the United States past the BIA's final deportation order when they choose to exercise their statutory rights of appeal.

constrained by the BIA's power of quasi-judicial review and the binding precedents established by the BlA's decisions. See 8 C.F.R. § 3.1(b), (g) (1994).

92. Hazime v. INS, 17 F.3d 136, 140 (6th Cir. 1994) (quoting Ashby v. INS, 961 F.2d 555, 557 (5th Cir. 1992)).

93. See United States ex rel. Klonis v. Davis, 13 F.2d 630, 630 (2d Cir. 1926).

94. See Kevin R. Johnson, Responding to the "Litigation Explosion": The Plain Meaning of Executive Branch Primacy over Immigration, 71 N.C. L. REv. 413, 417-18 (1993) (describing the Rehnquist Court's view that deportation should receive no more scrutiny by a reviewing court than a rate-setting decision).

95. See Elwin Griffith, Exclusion and Deportation-Waivers Under Section 212(c) and Section $244(a)(1)$ of the Immigration and Nationality Act, 32 DEPAUL L. Rev. 523, 532 (1983).

The term "hard look" derives from a line of District of Columbia Circuit cases where the court, in reviewing agency regulations, considered whether the agency's decision-making process was rational, whether the decision was reasonable, and whether the agency scrutinized the data, apart from the substantive statute. See Cass R. Sunstein, Deregulation and the Hard-Look Doctrine, 1983 Sup. CT. REv. 177, 181-82. The United States Supreme Court endorsed this approach in Motor Vehicle Mfrs. Ass'n v. State Farm Mut. Auto. Ins. Co., 463 U.S. 29 (1983). See also Robertson v. Methow Valley Citizens Council, 490 U.S. 332, 350 (1989) (citing Kleppe v. Sierra Club, 427 U.S. 390, 410 n.21 (1976)).

96. See INS v. Cardoza-Fonseca, 480 U.S. 421,449 (1987) (citing INS v. Errico, 385 U.S. 214, 225 (1966); Costello v. INS, 376 U.S. 120, 128 (1964); Fong Haw Tan v. Phelan, 333 U.S. 6, 10 (1948)). 


\section{Drastic Nature of Deportation}

Deportation strips departing aliens of any family, business, occupational, community; and emotional ties with this country. Various courts have labelled deportation a "dreadful punishment,"97 a near "Draconian criminal penalt[y],"98 and a "drastic"99 or "harsh" measure. ${ }^{100}$ When Congress imposed the seven-year domicile requirement, it contemplated that many of these ties would have taken hold in seven years. These ties form gradually, and the seventh year is not some magic point in time before which ahens have no meaningful ties or after which aliens do not develop their ties further. Even though the BIA's seven-year accrual clock stops ticking upon its entering an administratively final deportation order, the alien's family and economic ties continue to deepen. Thus, if an alien develops these ties in the course of seven years of physical presence in this country, deportation is an equally harsh measure whether or not these seven years were the result of lawful domicile.

Due to deportation's grave consequences, courts have recognized a long-standing and sensible principle that statutory ambiguities should be resolved in the ahen's favor. ${ }^{101}$ In the case of Mr. Lok, whose case before the BIA gave rise to the administratively final rule, the Second Circuit expressed humane consideration for Lok. ${ }^{102}$ Lok was married to an American citizen and was responsible for supporting his wife's children who were also American citizens. ${ }^{103}$ The court recognized that aliens like Lok should not be demed 212(c) relief where they have "sunken deep roots imto this land" despite not having permanent resident status for the full seven years. ${ }^{104}$ In granting Lok's petition for review of a final order of deportation and remanding the case to the BIA for reconsideration, the court noted that "the obvious purpose" of 212 (c) is to "mitigate the hardship that deportation poses for those with family ties in this country."105

\section{Keeping the Floodgates Closed}

Proponents of the Agency's administratively final rule argue that this rule is necessary to prevent frivolous filings by aliens who hope to accrue

97. United States ex rel. Klonis v. Davis, 13 F.2d 630, 630 (2d Cir. 1926).

98. Lok v. INS, 548 F.2d 37, 39 (2d Cir. 1977).

99. Fong Haw Tan v. Phelan, 333 U.S. 6, 10 (1948).

100. Cardoza-Fonseca, 480 U.S. at 449.

101. Costello v. INS, 376 U.S. 120, 128 (1964). The United States Supreme Court reaffirmed this principle in Cardoza-Fonseca, 480 U.S. at 449 . Other courts have cited this proposition, including the Second Circuit iu Rosario v. INS, 962 F.2d 220, 225 (2d Cir. 1992) and in Lok v. INS, 548 F.2d at 39.

102. Lok, 548 F.2d at $40-41$.

103. Id. at 41 n.3.

104. Id. at 39. In "Lok I," the Second Circuit remanded the case to the BIA on the basis that the BIA cited insufficient grounds for finding Lok ineligible for 212 (c) consideration. On remand, the BIA found Lok ineligible for 212 (c) rehef under its newly formulated administratively final rule. The Second Circuit then affirmed the BIA's decision in "Lok II," Lok v. INS, 681 F.2d 107 (2d Cir. 1982).

105. Lok, 548 F.2d at 41 (footnote omitted). 
their seven years during the pendency of their frivolous appeals. ${ }^{106}$ Not surprisingly, those circuits upholding the BIA's rule give considerable weight to the frivolous appeals argument. For example, the Fourth Circuit recognized the Board's concern that allowing accrual time during judicial review "would 'encourage spurious appeals to the courts' and reward aliens for prolonging an already lengthy process." 107

The Eleventh Circuit agreed, but was more forthright in its reasons for denouncing an extended accrual period. The court found untenable an alien's benefitting froin the docket congestion "which plagues the federal courts." 108 The court wished to ensure that no alien would be able to take advantage of any conceivable "procedural dilatory tactics."109 While federal appellate courts may have a backlog of cases, the Eleventh Circuit should vent its frustration at Congress, which granted the statutory right to judicial review, and not at the aliens seeking to exercise their statutory rights. ${ }^{110}$

Despite these alarm bells, the fears of frivolous filings are exaggerated. It is unlikely that an alien would accrue all or even most of the seven years during the pendency of judicial review. Most cases that are litigated would likely fall on the spectrum closer to that of Mr. Variamparambil, whose domicile are but days or months shy of the seven years required.

Second, the appeals process is costly. An alien attempting to exploit any loopholes via frivolous filings first would have to exhaust all adininistrative remedies. This involves filing all appeals in a timely fashion and remitting any filing fees. ${ }^{111}$ In addition to application fees, legal fees will almost certainly be incurred or, at the very least, legal aid enlisted. These transaction costs serve as great obstacles to the majority of aliens contemplating filing frivolous appeals.

Finally, the Ninth Circuit has adopted a practical approach to deal with this limited threat, without upholding the BIA's administratively final rule. The Ninth Circuit is aware that overly generous rules could permit endless applications for waivers even after physical deportation. ${ }^{12}$ However, rather than adopting a blanket administratively final rule, the court simply

106. See, e.g., Reiber, supra note 75 , at 646 .

107. Nwolise v. INS, 4 F.3d 306, 311 (4th Cir. 1993) (quoting In re Lok, 18 I. \& N. Dec. 101, 107 (BIA 1981)), cert. denied, 114 S. Ct. 888 (1994).

108. Marti-Xiques v. INS, 741 F.2d 350, 354-55 (11th Cir. 1984) (footnote omitted).

109. Id. at 355 .

110. The Eleventh Circuit noted in 1984 that federal courts of appeals filings had increased $56.6 \%$ since 1978. Id. at $355 \mathrm{n} .26$. However, the court did not indicate how much of that increase was due to section 212(c) appeals.

111. The alien must first complete and submit Form I-191, the 212(c) waiver apphication. The application fee is $\$ 50.00$. Deportation OfFicER's HANDBOOK, supra note 61, at 79. An alien denied 212(c) relief by an IJ has ten days in which to file an appeal with the BIA. 8 C.F.R. $\S \S 3.1(\mathrm{~b}), 3.38(\mathrm{a})$ (b) (1993). The alien then has ninety days in which to petition for judicial review. 8 U.S.C. $\S 1105$ a(a)(1) (Supp. V 1993).

112. Gonzales v. INS, 921 F.2d 236, 240 (9th Cir. 1990). 
refused to count any time consumed on appeal when the court deemed the appeal to be frivolous. ${ }^{113}$ This solution tempers the drastic nature of deportation by separating out the truly meritorious apphicants from the frivolous ones and giving deserving aliens the opportunity to seek relief.

\section{Statutory Conflicts}

Notwithstanding deportation's harsh consequences, the Agency's rule conflicts with the spirit of the statutory rights and administrative rules intended to benefit aliens. These include an alien's right to seek judicial review, to petition for an automatic stay of deportation, and to pursue a motion for the Board to reopen or reconsider the case. An alien should not be denied doinicile accrual time while exercising these rights.

Congress has conferred upon ahens the right to appeal an administrative denial of a 212 (c) waiver via judicial review in the federal courts. ${ }^{114}$ This right is conferred upon all apphcants denied 212(c) relief. At least one court, the Ninth Circuit, has recognized the importance of this right by allowing accrual time during the pursuit of this right to judicial review. ${ }^{115}$

The Agency's rule also conflicts with a deportee's right to petition for an automatic stay of deportation. Congress has directed the INS to stay a deportation, upon an ahen's request, pending the court's evaluation of the ahen's petition for review. ${ }^{116}$ While 212 (c) contemplates that an alien have seven years of lawful domicile, there is no indication that an alien remaining in this country under a stay of deportation is domg so unlawfully.

Furthermore, 212(c) was drafted with exclusion proceedimgs in mind, in which those excluded from entry do not have the right to request a stay of exclusion. ${ }^{117}$ Francis v. INS, however, imvoked the Equal Protection Clause to extend $212(\mathrm{c})$ relief to deportees. ${ }^{118}$ Just as the courts and the BIA have expanded 212 (c) to accommodate deportees, they should also mterpret 212 (c) to minimize administrative interference with the judicial rights given to deportees.

Finally, the administrative regulation governing the Board's reopening or reconsidering any of its previously decided cases require the alien's physical presence in the United States. ${ }^{119}$ The regulation unequivocally states that "[a]ny departure from the United States of a person who is the subject of deportation proceedings occurring after the nuaking of a motion

113. Torres-Hernandez v. INS, 812 F.2d 1262, 1264 (9th Cir. 1987) (holding that in a motion to reopen deportation proceedings to apply for 212 (c) relief, seven-year domicile time is not accrued by filing frivolous appeals).

114. 8 U.S.C. $\$ 1105 a(a)$ (Supp. V 1993).

115. Wall v. INS, 722 F.2d 1442, 1445 (9th Cir. 1984).

116. 8 U.S.C. \$ 1105a(a)(3) (Supp. V 1993).

117. 8 U.S.C. $\$ 1227$ (a)(1) (Supp. V 1993). This section provides that any alien "arriving in the United States who is excluded under this chapter, shall be immediately deported . ..."

118. Francis v. INS, 532 F.2d 268, 272-73 (2d Cir. 1976). The BLA adopted this position in In re Silva, 16 I. \& N. Dec. 26 (BIA 1976).

119. 8 C.F.R. \$ 3.2 (1993). 
to reopen or a motion to reconsider shall constitute a withdrawal of such motion."120 This provision forces aliens who wish to reopen their cases to remain in the United States. However, despite this continued physical presence, the BIA's rule does not allow aliens to earn "credit" for the additional time spent developing their ties with this country.

In sum, the Agency's administratively final rule is faulty. It does not measure up to Congress' overarching humane purpose for providing discretionary relief. It also falls short of Congress' concern over limiting the AG's and the Agency's discretion. The administratively final cutoff point is not sufficiently independent from the Agency's control to check the Agency's exercise of discretion. Finally, as a policy matter, this rule exacerbates the sufferings attendant to deportation and is inconsistent with those statutory rights designed to ease deportation's harshness. It is time to take a hard look at the Agency, its rule, and the rulemaking process.

\section{III}

\section{Agency Deferral Reconsidered: The Case for Courts to} INTERPRET STATUTES

As just shown, the Agency's administratively final rule is disturbingly flawed. This Part addresses whether the federal courts can and should intervene to save those aliens adversely affected by the agency's poorly conceived rule. In particular, should the courts defer to the Agency's interpretation of 212(c) or should the courts independently decide the meaning of 212(c)'s seven-year domicile requirement?

This Part argues in favor of the courts' taking a fresh look at 212(c) without the constraints of agency deference. First, a structural analysis of the United States Supreme Court's landmark Chevron ${ }^{121}$ decision reveals a "trap": inost appellate courts uphold agency decisions by applying the Chevron doctrine in a manner that precludes any meaningful evaluation of the administratively final rule. Second, the inerits of an alternative approach, INS v. Cardoza-Fonseca, ${ }^{122}$ will be explored. In CardozaFonseca, the Supreme Court assigued to the courts the task of interpreting "pure question[s] of statutory construction." 23 Interpreting "domicile" for 212(c) purposes is just sucli a case. While Chevron stands at one end of the spectrum of agency deference, Cardoza-Fonseca restores some balance by identifying the limits of this deference. Finally, policy reasons argue, in soine instances, for throwing off the shackles of agency deference and permitting the courts to go about their business of interpreting the law.

Whether the Agency or the courts should interpret 212(c) becomes relevant only in the absence of congressional action. The Court has recog-

120. Id.

121. Chevron U.S.A. Inc. v. Natural Resources Defense Council, Inc., 467 U.S. 837 (1984).

122. 480 U.S. 421 (1987).

123. Id. at 446 . 
nized Congress' plenary power over which aliens shall be admitted to the United States. ${ }^{124}$ Furthermore, appellate courts have urged Congress to clarify 212(c)'s "untidy patchwork."125 Therefore, Congress should decide what seven years of domicile really means. However, despite compelling reasons for clarification and Congress' power to amend 212(c), legislative imertia works against such a likelihood. ${ }^{126}$ Over 40 years have elapsed since the passage of the 1952 Act. Even with major immigration law revisions in 1986 and 1990, Congress passed up those opportunities to ainend 212(c)'s seven-year requirement. Because Congress has refused to clean up 212 (c)'s "untidy patchwork," the question of who decides is a relevant, if not urgent, one.

\section{A. Chevron and Beyond}

In using their technical expertise and exercising their delegated authority in handling immigration affairs, the INS and BIA are simply doing the job Congress has given them. Agencies understandably must also interpret the language of the statutes, because no statute, no matter how clearly or well-constructed, will be able to instruct them on low to handle every immigration case before them. However, Chevron tips the scales too mucl in favor of agencies' own imterpretations of statutes. Specifically regarding the BIA's administratively final interpretation of 212(c), this Section looks at Chevron's structural shortcomings, the trap which is created, and Chevron's misuse by the reviewing courts. ${ }^{127}$

\section{Chevron's Two-Step Analysis}

Many consider Chevron to be a landmark decision, if not the central case of modern administrative law. ${ }^{128}$ Despite its far-reaching effects, the

124. INS v. Chadha, 462 U.S. 919, 940-41 (1983). For a general discussion on Congress' plenary power over immigration, see Stephen H. Legomsky, Immigration Law and the Principle of Plenary Congressional Power, 1984 Sur. Cr. Rev. 255.

125. Campos v. INS, 961 F.2d 309, 315 (1st Cir. 1992). The First Circuit found that "the combined effect of $\$ 212$ (c) and the interpretation in Francis and its aftermath, is to create an untidy patchwork, even, one might say, a mess. It is hard to imagine that a congressman or senator who thought about the matter would be pleased with the present state of affairs. But we think the most propitious means of improvement lies with Congress." Id.

126. See Gumo Calabrest, A Common Law for the Age of Statutes (1982) (arguing that, because it is difficult to get legislatures to revise statutes once they are passed, the courts should adopt a common law process to update and replace obsolete laws). But cf. Chiravacharadhikul v. INS, 645 F.2d 248, 250 (4th Cir. 1981) (finding it "incredible" that Congress would let stand for over 26 years an INS 212(c) interpretation if the INS disregarded congressional intent), cert. denied, 454 U.S. 893 (1981).

127. As a historical note, the BIA's administratively final rule was enunciated in Lok prior to the Chevron decision. The line of appellate court cases by the Fifth, Seventh, and Eleventh Cireuits firmly upholding the BIA's nule took shape after Chevron. See supra notes 51-56 and accompanying text. Because Chevron was so instrumental in ereating this alliance of Circuits, Chevron took agency deference to new heights.

128. See, e.g., Michael Herz, Deference Running Riot: Separating Interpretation and Lawmaking under Chevron, 6 Admin. L. J. 187, 187 (1992); Russell L. Weaver, Some Realism about Chevron, 58 Mo. L. REv. 129, 129 (1993). 
issue in Chevron was narrow. In Chevron, the Court had to decide whether the Environmental Protection Agency's ("EPA") single "bubble" rule was a reasonable construction of "stationary source," a term used in the Clean Air Act Amendments of 1977. ${ }^{129}$ The Act required certain states to regulate inajor stationary sources of air pollution. The EPA decided to allow states to treat all pollution-emitting devices of the same industrial plant as a single "bubble" constituting a single stationary source. ${ }^{130}$ Thus the EPA would allow one piece of equipment in an industrial plant to exceed the pollution limit for that device, provided that another piece of equipment was modified to keep the total plant emissions within the pollution limit. ${ }^{131}$

In reaching its decision, the Court developed a two-step test to determine if the EPA's interpretation was permissible. The Court further admonished the reviewing courts that if the two-step test is met, the agency's interpretation should survive judicial scrutiny even though the reviewing court would not have inade the same interpretation. Under these guidelines, the Court upheld the EPA's rule. ${ }^{132}$

Step one of the test asks the question whether "Congress has directly spoken to the precise question at issue."133 If the answer is "yes," then Congress' intent is clear and "that is the end of the inatter."134 The courts and the agency nuust adhere to Congress' unambiguous intent. If the courts determme that Congress has not directly spoken, the courts may still not impose their own statutory construction. The courts nlust proceed to step two.

Step two asks whether the agency's interpretation of the ambiguous statute is based on a "permissible construction of the statute."135 If Congress has left a gap in the statute for the agency to fill, then Congress has delegated to the agency the authority to issue a regulation filling this gap. ${ }^{136}$ Accordingly, a court reviewing the agency regulation must uphold the regulation unless it is "arbitrary, capricious, or mamifestly contrary to the statute."137 Agency deference derives fronl the principle that the courts should give considerable weight to the agency's statutory construction, according to congressional mandate. In short, if an agency's interpretation of an ambiguous statute is reasonable, it stands.

Furthermore, even where Congress has only implicitly delegated gapfilling to the agency, a court niay "not substitute its own construction of a

129. Pub. L. No. 95-95, 91 Stat. 685 (1977).

130. Chevron U.S.A. Inc. v. Natural Resources Defense Council, Inc., 467 U.S. 837, 840 (1984).

131. Id.

132. Id. at 866 .

133. Id. at 842.

134. Id.

135. Id. at 843 .

136. Id. at 843-44.

137. Id. at 844 (footnote omitted). 
statutory provision for a reasonable [agency] interpretation."138 The Court makes clear that the reviewing court's mission is not to search for the best statutory interpretation, but to determine if the agency's interpretation is reasonable. ${ }^{139}$ Thus, under Chevron agencies interpret ambiguous statutes; reviewing courts decide whether such interpretations are reasonable.

\section{The Chevron Trap in Section 212(c) Cases}

Chevron's two-step approach tips the balance in favor of the agency's interpretation of an ambiguous statute. This feature does not in itself make Chevron a poor test. After all, the Court favored agency deference precisely to carry out Congress' intent to delegate authority to the agencies where appropriate. The problein with Chevron is that in the 212(c) cases appearing before the appellate courts, it almost inevitably leads reviewing courts to uphold agency decisions concerning the ambiguity in the statute. Chevron is a trap because a court's invocation of it signals that the reviewing court will uphold the BIA's interpretation of 212(c) requirements. As such, Chevron fails as a meaningful approach to evaluate the BIA's administratively final rule.

\section{a. Step One: $A$ Wide Open Door to Agency Deference}

The problem arises at each step of Chevron's two-step approach. In step one, it is difficult to answer "yes" to the question whether Congress has directly spoken to the precise question at issue. ${ }^{140}$ Section 212(c)'s structural "untidy patchwork" and empirical evidence reveal that the courts" answer to step one is almost always "no." Because a "no" response automatically leads to step two, step one permits too many agency interpretations to enter the deference door.

In the inore than forty years since 212(c) was enacted, administrative and judicial decisions have altered the scope and requirements of this waiver provision. Various courts have referred to 212 (c) as an "untidy

138. Id.

139. Id. The Court stated that the reviewing court "need not conclude that the agency construction was the only one it permissibly could have adopted to uphold the construction, or even the reading the court would have reached if the question initially had arisen in a judieial proceeding." Id. at 843 n.11 (citations omitted).

140. If Congress were direct and precise in writing the statute, there would be little controversy over the agency's interpretation. However, because many, if not most, statutes are inhercntly ambiguous, rarely can a court confidently assert that Congress directly spoke using precise statutory language. See Daniel B. Rodriguez, Statutory Interpretation and Political Advantage, 12 INT'L REv. L. \& ECoN. 217, 219 (1992) (arguing that a large number of statutes are ambiguous because Congress intended, if not manufactured, these ambiguities). Furthermore, under Justice Scalia's "plain meaning" approach, Chevron essentially becomes a one-step test. Justice Scalia takes a literalist view of statutory interpretation and rejects attempts to identify congressional intent outside the text of the statute. Therefore, whether Congress has directly and precisely spoken is determined wholly within the confines of the statutory text. See Johnson, supra note 94, at 426 (discussing approaches to statutory interpretation). 
patchwork," a "mess,"141 and even "soup" rendered inedible by "[t]oo many cooks."142 This untidiness makes extrapolating Congress' intent difficult. The BIA's decision to extend 212(c) relief to deportees makes this task all but impossible: the issue of when an alien ceases to accrue domicile time for 212(c) purposes arises only in the case of deportees, a situation not contemplated by the express language of the statute. Thus, by definition, section 212(c) is silent regarding questions involving deportees. Under Chevron, step one inust be answered "no."

This analysis, however, leads to a very disturbing result. The BIA's interpretation made it past step one only because the Agency previously expanded the scope of the statute, making it impossible for Congress to have spoken directly on the precise question at issue. Thus, because the Agency chose to construe 212(c) liberally to save the statute from constitutional infirmity, the Agency now appears to have enabled itself to receive deference for all questions deriving from this prior construction.

Empirical evidence also shows that when reviewing courts apply Chevron, they almost always breeze past step one. In a sampling of 212(c) cases where the reviewing court used the Chevron analysis, almost all made it to step two. ${ }^{143}$ Many reviewing courts analyze whether Congress directly spoke in cursory fashion, oftentimes leaping past step one in a single sentence. For example, in Jaramillo v. INS, the Eleventh Circuit asserted, "Congress did not speak directly to the precise issue of when lawful domicile ends for § 212(c) purposes, so we are past the first step of the Chevron analysis. This case is about the second step ...."144 Thus, in 212(c) cases, step one provides little obstacle to reaching agency deference under step two.

\section{b. Step Two}

Just as the reviewing courts nearly always answer "no" in step one, the courts almost always answer "yes" in step two-that the agency's interpretation is a permissible statutory construction. The reasons for this result are twofold. First, Chevron imposes a lenient standard of judicial review in step two. Reviewing courts may strike down an agency interpretation as unreasonable only if it is "arbitrary, capricious, or manifestly contrary to the statute." 145 This standard of review is similar to that prescribed under

141. Campos v. INS, 961 F.2d 309, 315 (1st Cir. 1992).

142. Butros v. INS, 990 F.2d 1142, 1152 (9th Cir. 1993) (Trott, J., dissenting).

143. In a Westlaw "natural language" search of the federal court of appeals database conducted in September 1994 for the terms "212(c)" and "Chevron," eighteen cases were retrieved. Fifteen reached step two of the Chevron analysis. See, e.g., Nwolise v. INS, 4 F.3d 306, 309 (4th Cir. 1993), cert. denied, 114 S. Ct. 888 (1994); Jaramillo v. INS, 1 F.3d 1149 (11th Cir. 1993); Katsis v. INS, 997 F.2d 1067 (3d Cir. 1993), cert. denied, 114 S. Ct. 902 (1994); Variamparambil v. INS, 831 F.2d 1362, 136667 (7th Cir. 1987).

144. Jaramillo, 1 F.3d at 1152.

145. Chevron U.S.A. Inc. v. Natural Resources Defense Council Inc., 467 U.S. 837, 844 (1984). 
section 706 of the Administrative Procedure Act ("APA"), which sets aside agency action that is "arbitrary, capricious, an abuse of discretion, or otherwise not in accordance with law."146 However, Chevron's stronger deference language suggests that under step two, reviewing courts may find it more difficult than under the APA to overturn an agency's decision. Whereas the APA sets aside agency actions "not in accordance with law," Chevron demands that agency decisions rise to the level of beimg "manifestly contrary to the statute" before they are stricken. Thus, only the most egregious or erroneous interpretations of 212(c) will fail under Chevron step two.

Second, because step two rehes in part on the answer to step one, it is unsurprising that step two also inore often than not results in a foregone conclusion. To illustrate, take the case of Cabral v. INS, ${ }^{147}$ in which the First Circuit employed Chevron in a deportation appeal. In the court's words, step one looks to see whether "the literal words of the statute create ambiguity." "contrary to clear congressional intent."149 If, however, the statute's ambiguity forces the analysis to step two, how can administrative constructions ever be found contrary to clear congressional intent, which under step one was found to be ambiguous? Thus, this circular reasoming makes it difficult to find agency interpretations unreasonable, where the statute-against which reasonableness is ineasured-is itself ambiguous. ${ }^{150}$

The effect of this logical loop is that, with regard to 212(c), Chevron steps one and two, rather than serving as checkpoints, create a judicial rush toward agency deference. Once a reviewing court marches down the Chevron path, it rarely overturns the agency's decision. ${ }^{151}$

146. 5 U.S.C. $\$ 557$ (1988). Under the APA, formal adjudications (including hearings before immigration judges) require findings, conclusions of law, and the reasons for the agency's decision. Id. A reviewing court evaluates the agency's decision based on the administrative law judge's reasons and findings and sets aside the agency's action only if it is found to be "arbitrary, capricious, an abuse of discretion, or otherwise not in accordance with law." 5 U.S.C. $\$ 706$ (1988). Two judicial approaches emerged to determine "abuse of discretion." The approach in Citizens to Preserve Overton Park, Inc. v. Volpe, 401 U.S. 402 (1971), overruled on other grounds, Califano v. Sanders, 430 U.S. 99 (1977), looks at the substantive statute's requirements to determine whether an agency decision is reasonable. The approach in Motors Vehicle Mfrs. Ass'n v. State Farm Mut. Auto. Ins. Co., 463 U.S. 29 (1983) considers reasonableness according to how adcquately the agency explained its decision.

147. 15 F.3d 193 (1st Cir. 1994).

148. Id. at 194 (quoting United States v. Charles George Trucking Co., 823 F.2d 685, 688 (1st Cir. 1987)) (emphasis added).

149. Id. (quoting Mosquera-Perez v. INS, 3 F.3d 553, 555 (Ist Cir. 1993) (citation omitted)) (emphasis added).

150. Chevron becomes even more circular if Congress intended and designed the statute to be ambignous. In these cases, Chevron would tip the scales in favor of agency deference, when in fact Congress may have had other rcasons for ambiguity. See supra note 140.

151. Although Chevron usually results in agency deference, the reviewing courts do not rubberstamp agency decisions. Returning to the Westlaw search discussed supra note 143, of the fifteen cases employing Chevron's second step, eleven resulted in agency deference. This approximately $73 \%$ rate of 


\section{Chevron Abused and Misapplied \\ a. Judical Abuse}

Compounding Chevron's pro-agency structural bias is the reviewing appellate courts' abuse of Chevron. When 212(c) cases appear before the courts, nearly half of them are decided under Chevron's analysis. ${ }^{152}$ Examination of these appellate court opinions suggests a pattern of using Chevron as a post-hoc rationalization for upholding agency rules. ${ }^{153}$ Instead of employing Chevron's two-step test to analyze whether agency deference is appropriate, the courts cite to Chevron as a starting point-as a premise for agency deference.

A pair of recent Fifth Circuit deportation cases illustrate this point. In its brief, two-page opmion in Fonseca-Leite v. INS, ${ }^{154}$ the court affirmed the BIA's denial of petitioner's deportation suspension. Petitioner was convicted of two firearms violations, which led the INS to initiate deportation proceedings. The BIA upheld the IJ's denial of a deportation stay. Petitioner appealed to the Fifth Circuit. In considering petitioner's appeal, the court did not specifically address petitioner's eligibility for relief, but headed straight for Chevron. The court noted at the outset that "we are constramed to give considerable deference to the BIA's interpretation of the legislative scheme it is entrusted to administer."15s

Compare this to the same circuit's approach in Diaz-Resendez $v$. INS. ${ }^{156}$ Here the court vacated and remanded the BIA's decision denying 212(c) relief. ${ }^{157}$ The 54-year-old petitioner was a lawful perinanent resident for 37 years, had been married to a United States citizen for 29 years, and had three dependent children. His only crimes were a drunk driving arrest and a nuarijuana possession conviction. The IJ and the BIA denied petitioner's request for a 212(c) waiver. However, in vacating the BIA's decision, the Fifth Circuit cited Overton Park ${ }^{158}$ for the proposition that the court must "engage in a substantial imquiry, ... a thorough, probing, indepth review of [the] discretionary agency action."159 Overton Park has been recognized as a "high-water mark of judicial scrutiny" calling for

deference supports the argument that Chevron leads to agency's decisions surviving judicial review; it does not mean that Chevron automatically results in agency deference.

152. A Westlaw search conducted in March 1994 found a sampling of 212(c) cases adjudicated by federal appellate courts after Chevron was decided. Of the 31 cases retrieved fourteen cited Chevron. See supra note 143.

153. 69 INTERPRETER ReleAses 1336 (1992).

154. 961 F.2d 60 (5th Cir. 1992).

155. Id. at 62 .

156. 960 F.2d 493 (5th Cir. 1992).

157. Id. at 498 .

158. Citizens to Preserve Overton Park, Inc. v. Volpe, 401 U.S. 402 (1971), overruled on other grounds, Califano v. Sanders, 430 U.S. 99, 105 (1977).

159. 960 F.2d at 495 (quoting Overton Park, 401 U.S. at 416 ) (alteration in original). 
stronger review of agency actions. ${ }^{160}$ The court made no reference to Chevron.

It is difficult to explain the court's rationale for choosing Chevron in one case but not the other. Even though different rules within section 212 were involved, the court did not indicate why Chevron was a critical starting point im Fonseca-Leite but not in Diaz-Resendez. One commentary bluntly asserts that the determining factor is the "court's gut feeling about the alien's worthiness for relief."161 Thus, when a court is not sympathetic to an alien's plight it can cite Chevron, but when it is, it can cite Overton Park. Used in this manner, Chevron becoines less a test of when agency deference is appropriate and more a rationalization for the end result-a means for denymg petitioner's relief.

\section{b. Misapplication}

In addition to abusing Chevron in 212(c) cases generally, the courts more seriously err when they apply Chevron to the specific question of interpreting 212(c)'s seven-year domicile requireinent. The Chevron opinion does not propose a blanket rule of agency deference. Chevron's scope is limited. Agency deference may hinge on whether the agency's rule is a "legislative" or "interpretive" one. ${ }^{162}$ A careful reading of Chevron indicates that step-two deference applies only to an agency's legislative rules, but not to its interpretive rules. ${ }^{163}$ Because, as will be argucd, the BIA's administratively final rule is an interpretative rule, courts misapply Chevron when evaluating the BIA's construction of the seven-year domicile requirement.

Traditionally, legislative rules have been distinguished from interpretive ones under a two-pronged definition. ${ }^{164}$ First, a legislative rule has the "force and effect of law"; 165 it creates new law. In contrast, an interpretive rule "merely states the agency's view of what the statute already requires."166 Whereas legislative rules are theinselves the primary sources of legal obligations, interpretive rules recognize that the statute remains the basis of any legal obligations. ${ }^{167}$ Second, legislative rules result from

160. See 69 INTERPRETER RELEASES 1336 (1992).

161. Id.

162. See Herz, supra note 128 , at 190-92.

163. Id. at 190. See generally Richard A. Posner, Legislation and Its Interpretation: A Primer, 68

NEB. L. REv. 431 (1989) (discussing the legislative process and statutory intcrpretation).

164. Herz, supra note 128 , at 191-92.

165. Batterton v. Francis, 432 U.S. 416, $425 \mathrm{n.9}$ (1977) (citation omittcd); Board of Educ. v. Harris, 622 F.2d 599, 613 (2d. Cir. 1979), cert. denied, 449 U.S. 1124 (1981).

166. Herz, supra note 128 , at 191-92 (footnote omitted).

167. An example of a legislative rule is an agency rule promulgated pursuant to a statute that expressly instructs the agency to issue rules or standards. See, e.g., Batterton v. Francis, 432 U.S. at 425 (noting that the Health, Education, and Welfare secretary issued a legislative rule when he promulgated standards defining "unemployment" as required by 42 U.S.C. $\$ 607(a)$ ). 
Congress' specific instruction to the agency to create rules. ${ }^{168}$ Such rules are legislative because Congress expressly delegates to the agency legislative, ruleinaking authority. Agency rules not adopted by virtue of specific congressional delegation, such as rules adopted to carry out the administration of statutes, inay be regarded as interpretive.

This distinction between legislative and interpretative rules can be found in Chevron itself. Michael Herz presents the case that "Chevron is about legislative rather than interpretive rules," and thus that Chevron deference may be applied to legislative but not interpretive rules. ${ }^{169} \mathrm{Herz}$ argues that although Chevron repeatedly refers to "an agency's construction of the statute" and "deference to administrative interpretations," the Court uses the terms "construction" and "interpretation" in the sense of the agency's legislative capacity. ${ }^{170}$ The Court deferred not to the EPA's reading of the Clean Air Act, but to its congressionally delegated lawmaking. Thus, when properly applied, Chevron requires that courts stop at step one and withhold deference where the agency rule under scrutiny is interpretive and where Congress did not expressly delegate to the agency binding interpretive authority. ${ }^{171}$

Alternatively stated, deference to the administrative construction of the statute is not absolute. ${ }^{172}$ When an agency engages in the quasi-judicial function of determining a statute's meaning, its interpretation is influential, but not binding. Under the second prong of the interpretive/legislative distinction, interpretive rules require less deference because they come with diminished congressional authority. In contrast, when an agency engages im legislative functions, its rules require more deference.

Within this definitional framework, the BIA has non-binding interpretive, not binding legislative authority. With respect to 212 (c), Congress established a specific set of eligibility requirements which the BIA nay attempt to interpret, but by no means may create. As such, the BIA's administratively final domicile rule more closely fits the interpretive rule definition than the legislative one.

In contrast, an "interpretative rule is . . . an explanation of particular terms in an Act. If you had an expression in a statute such as 'Interurban Railway,' the query might come up as to what is an 'interurban railway.' A particular agency may adopt a rule defining an interurban railway. That, in a sense, may be called an interpretative rule." Batterton v. Marshall, 648 F.2d 694, 705 (D.C. Cir. 1980) (quoting Gibson Wine Co. v. Snyder, 194 F.2d 329 (D.C. Cir. 1952)).

168. Herz, supra note 128 , at 192.

169. Id. at 199 .

170. Id. at $199 \& \mathrm{n} .68$ (emphasis in original).

171. Herz indicates that Chevron is silent regarding how courts should treat an agency's interpretation of Congress' decision. He suggests that the agency's interpretative rules should be influential but not binding, citing to older cases such as Skidmore v. Swift \& Co., 323 U.S. 134, 140 (1944), wherein the Court found interpretative rules "not controlling upon the courts." Hertz, supra note 128 , at 193. Only when Congress has explicitly given the agency binding interpretive authority is step two appropriate. Id. at 200-01.

172. See Bureau of Alcohol, Tobacco \& Firearms v. Federal Labor Relations Auth., 464 U.S. 89, 97-98 (1983) (citation omitted). 
Under the first prong of the "interpretive" definition, the Agency's decision is an interpretive rule, which does not have the "force of law." The BIA's opinions themselves suggest that the BIA recognizes that it is not itself the source of law for deciding what is "domicile." For example, in determining whether an alien was eligible for 212(c) rehef in In re Sanchez, ${ }^{173}$ the BIA based its decision on its understanding of the term "domicile." The BIA wrote: The word 'domicile' in section 212(c) refers to the legal concept of being a domiciliary of the United States. ... Thus in order for an alien to establish 'domicile' in the United States, he inust be physically present here and have the intention of making the United States his home ....".174 The BIA then cited a string of United States Supreme Court, appellate court, and district court cases as authority for this proposition. Thus, the BLA admitted that "domicile" is a legal term of which it must look to the statute and to the federal courts for a definition. ${ }^{175}$ In other words, "domicile" is not what the BIA says is "donicile," because the real definition of domicile ultimately rests with Congress or the federal courts.

Under the second prong, interpretive rules, unlike legislative rules, are not adopted pursuant to a specific delegation of rulemaking authority. In the 212(c) case, Congress did not specifically instruct the BIA or the INS to issue rules regarding 212(c)'s eligibility requirements. ${ }^{176}$ This observation is readily apparent from 212(c)'s two-part structure. The first part lays out aliens' eligibility requirentents for relief; the second part gives the AG discretion to grant relief once the part-one requirentents are niet. ${ }^{177}$ Part one thus cabims the discretion granted to the AG in part two. If Congress did instruct the Agency to issue rules regarding the part-one eligibility requirements, then Congress would be giving the AG the discretionary authority to decide when she has this discretionary authority. Surely Congress did not intend for the AG to determine the scope of her own authority, especially where this authority is an express grant of discretionary power. ${ }^{178}$ There-

173. 17 I. \& N. Dec. 218 (BIA 1980).

174. Id. at 221 (citations omitted).

175. To an extent all statutory terms are legal concepts or legal "terms of art." The issue here, however, is whether the agency or Congress/courts give these terms their legal force. See CALABrESI, supra note 126, at 31 (arguing that "[w]ords do not interpret themselves").

176. The BIA has developed a rule outlining the favorable and adverse factors which the agency considers in deciding whether to grant discretionary 2I2(c) relief. However, this list of the so-called "Marin" factors is a rule regarding the agency's discretionary exercise of power, not a rule about 212(c)'s eligibility requirements. This Comment is concemed with the latter.

177. Although the statute refers to the $A G$, the $A G$ as head of the Department of Justice delegates this 212(c) discretionary authority to the INS and the BIA. Thus, for Chevron analysis purposes, "the agency" and "Attorney General" are interchangeable.

178. Congress defined "Tesidence" for 212(c) purposes, but not "domicile." See 8 U.S.C. \$1101(a)(33) (1988). Could Congress' silence be an implicit delegation of authority to the agency to decide what is meant by domicile? At least one reviewing eourt has said "no." The Second Circuit held that "[a]s it is assumed Congress intends words to have their ordinary meaning, it is appropriate to define domicile in reference to its generally accepted common law meaning if to do so does not defeat the purposes of the statute." Rosario v. INS, 962 F.2d 220, 223 (2d Cir. 1992) (eitations omitted). The 
fore, under either prong of the interpretive/legislative rule definition, the BIA's administratively final rule regarding domicile is merely an interpretive rule to which reviewing courts need not defer.

In sum, Chevron greatly impacts administrative law cases appearing before the appellate courts. Chevron rightfully tips the scales of deference in the agency's favor. However, Chevron's pro-agency bias has resulted in too many 212(c) cases decided against resident aliens, the group Congress intended 212(c) to benefit. The pattern of the appellate court's postChevron 212(c) opinions suggests that Chevron creates a "trap," froin which it is difficult to escape agency deference. Compounding the problem is the reviewing courts' misuse of Chevron when evaluating the BIA's administratively final domicile rule. By blurring the distinction between legislative and interpretive rules, the courts are forgetting Chevron's underlying premise - that agency deference derives froin Congress' delegation of authority. The next part argues an existing viable alternative to Chevron for analyzing $212(\mathrm{c})$ cases. ${ }^{179}$

court thus understands Congress' silence as defaulting to the common law and not automatically deferring to the agency's "domicile" interpretation.

179. If the reader is still unconvinced that Chevron does not apply to the 212 (c) case, then the Agency's administratively final rule should fail even under step two analysis of Chevron. Step two permits the courts to vacate and remand agency decisions which are "arbitrary, capricious, or manifestly contrary to the statute." Chevron U.S.A. Inc. v. Natural Resources Defense Council, Inc., 467 U.S. 837, 844 (1984). The agency rule may be arbitrary and capricious for two reasons.

First, under the Overton Park approach, see supra note 146, the BIA's decision is arbitrary and capricious if the BIA did not consider all of the relevant factors under the statute. In its Lok decision, the BIA examined four stages in the deportation process when the alien's lawful permanent residence and domieile status could be terminated for 212(c) purposes. The BIA considered these possibilities: (1) upon the IJ's initial determination of deportability; (2) when the IJ's order becomes administratively final; (3) when a court of appeals acts upon a petition for review of the Board's order or the time allowed for filing such petition expires; or (4) only upon the cxecution of the deportation order by the alien's departure from this country. In re Lok, 18 I. \& N. Dec. 101, 105 (BIA 1981). Althougl these points in time appear to cover the full range of possibilities, they are all agency-based and do not consider the possibilities from the alien's perspective. For example, why not terminate domicile at the moment the alien concedes deportability even thougl the ahen's deportation is not administratively final? This situation arises when an alien concedes deportability but raises a 212(c) claim which is pending beforc the BIA. See, e.g., Avila-Murrieta v. INS, 762 F.2d 733, 736 (9th Cir. 1985) (holding that an alien's lawful domicile for 212(c) purposes terminated upon conceding deportability because he relinquished his lawful intent to remain in this country). The BIA's analysis also does not contemplate the alien's moving to reconsider or rcopen the case. See, e.g., Butros v. INS, 990 F.2d 1142, 1145 (9th Cir. 1993) (holding that as long as the Board may reconsider or reopen the case, the alien's 212(c) status is not administratively final).

Second, under State Farm, 463 U.S. 29 (1983), the BIA inadequately explained its decision. In adopting the administratively final over the judicially final rule, the Board explained that "in contrast to the Board's de novo rcview powers, the appellate courts' scope of review is limited." In re Lok, 18 I. \& N. Dec. at 107. Thus, the Board's decision hinged on its belief that the BIA had de novo review powers whereas the reviewing courts did not. However, APA $\S 706(2)(F)$ grants de novo review to the reviewing courts, at least to the extent that the agency's fact-finding procedures are inadequate. See 5 U.S.C. $\$ 706(2)$ (F) (1988). Moreover, where pure questions of law are involved, the reviewing eourts review de novo the Board's determinations, including 212(c) decisions. See, e.g., Butros, 990 F.2d at 1144 ("We review de novo the Board's dctermination of purely legal questions regarding the requirements of the Immigration and Nationality Act.') (citation omitted); Cabral v. INS, 15 F.3d 193, 


\section{B. Cardoza-Fonseca: A Way Out?}

Chevron stands for agency deference, but there is a limit to this deference. Courts are obliged to follow the statute before they follow the agency. ${ }^{180}$ Chevron itself embodies this notion by declaring that the "judiciary is the final authority on issues of statutory construction and must reject administrative constructions which are contrary to clear congressional intent." 181 The Supreme Court gave force to these words in INS $v$. Cardoza-Fonseca. ${ }^{182}$

Cardoza-Fonseca may provide an alternative approach to Chevron in deciding whether the BIA's administratively final rule deserves deference. First, Cardoza-Fonseca reminds the courts that, despite Chevron's deference principle, the judiciary should not shirk its traditional responsibility of statutory interpretation. The courts, says Cardoza-Fonseca, are the final arbiters of statutory construction. ${ }^{183}$ Second, Cardoza-Fonseca deals specifically with a BIA/INS interpretation. While Cardoza-Fonseca may broadly apply to other administrative agencies, it is at the same time agency-specific in its recognition that "[d]eportation is always a harsh measure."184 Thus, courts reviewing 212(c) cases should at least balance a Chevron approach with Cardoza-Fonseca considerations.

\section{Pure Questions of Statutory Construction}

The issue in Cardoza-Fonseca was whether the "well-founded fear" and the "clear probability of persecution" standards for granting asylums were the same, as the INS and the BIA had ruled. ${ }^{185}$ In rejecting the Agencies' interpretation, the Court held that whether Congress intended the two standards to be identical is "a pure question of statutory construction for the courts to decide."186 The Court rejected the INS' plea for agency deference. $^{187}$

194 (1st Cir. 1994) ("As the petition for review presents a pure issue of statutory construction, we review de novo ....") (citations omitted). Because the reviewing courts also have de novo review powers, the Board does not adequately explain why the administratively final rule is superior to the judicially final rule.

Because the BIA failed to consider all possibilities in establishing a termination of domicile date and because it failed to adequately explain its decision, the BIA's rule is arbitrary and capricious.

180. Herz, supra note 128, at 216.

181. Chevron U.S.A. Inc. v. Natural Resources Defense Council, Inc., 467 U.S. 837,843 n.9 (1984).

182. 480 U.S. 421 (1987). Justice Steveus authored both the Chevron opinion-the landmark case of agency deference-and the Cardoza-Fonseca opinion, which limited Chevron's reach.

183. Id. at $446-48$.

184. Id. at 449.

185. Id. at $424-25$.

186. Id. at 446. Cardoza-Fonseca's "pure question" analysis is grounded in the APA's section 706 scope of review provision. Section 706 requires that "the reviewing court shall decide all relevant questions of law." 5 U.S.C. $\$ 706$ (1988).

187. Cardoza-Fonseca, 480 U.S. at 445. 
Two possibilities emerge that reconcile Cardoza-Fonseca's language of a "pure question of statutory construction" with Chevron's two-step analysis. One take on Cardoza-Fonseca is that it is an exception to Chevron. When courts can identify an issue as being a "pure question of statutory construction," they can interpret the statute on their own, outside the Chevron framework. A second possibility is that Cardoza-Fonseca attempts to restore ineaning to Chevron's step one by providing a clear instance where step one is answered affirmatively-that Congress has spoken directly. Under either reading, when 212(c) domicile ceases is just such a "pure question."

While Cardoza-Fonseca does not itself provide a useful guide for determining when a question is a pure question, two lines of earlier Supreme Court cases distinguish naked questions of law from mixed questions of law and fact. One set of cases is illustrated by NLRB v. Hearst Publications, Inc. ${ }^{188}$ where the Supreme Court upheld the NLRB's decision that street corner "newsboys" were "einployees" covered under the National Labor Relations Act ("NLRA"). Finding that this was a mixed question of law and fact, the Court held that it was proper for the Agency to decide this issue. The Court accorded special weight to the Agency's decision, citing the Board's "[e]veryday experience" and "familiarity" with practical, administrative problens arising under the NLRA. ${ }^{189}$

In the second line of cases, illustrated by Packard Motor Car Co. $v$. $N L R B,{ }^{190}$ the Supreme Court upheld the NLRB's decision that shop "foremen" were "employees" within the NLRA's ineaning. Here, the Court called this issue a "naked question of law," which the Court, not the NLRB, should decide. Although the Court arrived at the same result as the NLRB, the Court refused to defer to the Board or to give the NLRB's decision any special weight.

Whether newsboys or foreinen are employees under the NLRA appears to depend equally upon the facts. However, these two cases may be distinguished and reconciled if the Court regards as "pure" those questions whose facts recur more often and are better known, such as those surrounding shop foreinen in Packard, and considers as "mixed" those issues that arise more interstitially, as with newsboys in Hearst. ${ }^{191}$

188. 322 U.S. 111 (1944).

189. Id. at 130 .

190. 330 U.S. 485 (1947). The particular question with which these cases are concerned is no longer at issue because these holdings have been superseded by statute. See NLRB v. United Ins. Co., 390 U.S. 254, 256 (1968) (noting that Congress amended the NLRA definition of employee). However, the doctrinal distinction remains valid. See Stephen Breyer, Judicial Review of Questions of Law and Policy, 38 ADmin. L. Rev. 363, 367 (1986) (discussing Hearst's and Packard's "spiritual descendants").

191. See Herz, supra note 128 , at 223 n.170, 224 n.172. Many courts and commentators also reconcile these two decisions by considering congressional intent. Courts may find a pure question of law, as in Packard, when the Court believes Congress has provided the answer in the statutes. In contrast, courts may defer mixed questions to the agency, as in Hearst, when the Court believes 
As applied to the BIA's administratively final rule, whether domicile time accrues during the pendency of judicial appeal may arguably be a question of law for the courts to decide. First, section 212(c) of the statute uses the phrase "lawful unrelinquished domicile of seven consecutive years." 192 What constitutes lawful domicile is, at least on its facc, a question of law. It does not depend on any factual findings by the IJ or the BIA, but depends on the statute's construction and on the immigration laws generally. Furthermore, the issue of lawful domicile under section 212 (c) is recurrent. ${ }^{193}$ Whereas Congress may leave interstitial and obscure questions for the BIA to decide, Congress probably did not intend that the BIA create new rules determining, and not simply interpreting, lawful doinicile under the Immigration and Nationahity Act.

Second, while it might be argued that Cardoza-Fonseca would cast too wide a net if the courts can decide an issue, independent of the agency's determination, any time "lawful" is included in a statutory provision, even under a narrower reading of Cardoza-Fonseca, the lawful domicile issue presents a pure question for the courts to decide. In Cardoza-Fonseca, the Court carefully pointed out that it was deciding a "narrow legal question" whether the two asylum standards were the same and was not atteinpting to set forth a detailed description of how these standards should be applied. ${ }^{194}$

Similarly, here, the courts should decide whether Congress intended "doinicile" and "residence" - terms both used in 212(c)-to have the same ineaning. This question is properly one of pure statutory construction. Under Cardoza-Fonseca, the courts need not go so far as to decide how the domicile or residency tests are applied, but the courts should at least determine whether "domicile" and "residence" are the same. Such judicial clarification would affect the Agency's interpretation of lawful seven-year domicile, because the BIA's administratively final rule both obscures and relies on the relationship between these terms.

In its Lok decision, the BIA concluded that the "loss of lawful permanent resident status is a necessary corollary to the loss of lawful doinicile."195 The Board then went on to conclude that its administratively final rule applied to the termination of both lawful permanent resident status and lawful domicile. ${ }^{196}$ However, whether the Board can inake this "necessary

Congress intended that the agency should apply the facts to the statute. In these cases, Congress delegated authority to the agency to use its expertise in resolving mixed questions of law and fact. See Sanford N. Caust-Ellenbogen, Blank Checks: Restoring the Balance of Powers in the Post-Chevron Era, 32 B.C. L. REv. 757, 769 (1991); Herz, supra 128, at 224; Kenneth W. Star et al., Judicial Review of Administrative Action in a Conservative Era, 39 ADMIN. L. REv. 353, 368 (1987).

192. 8 U.S.C. $\S 1182$ (c) (Supp. V 1993).

193. See, e.g., cases cited supra notes 45-56.

194. INS v. Cardoza-Fonseca, 480 U.S. 421,448 (1987).

195. In re Lok, 18 I. \& N. Dec. 101, 105 (BIA 1981).

196. Id. at 105-06. The BIA glossed over this distinction between "domicile" and "residence." In Lok, the BIA wrote: 
corollary" is a question of law for the courts to decide. ${ }^{197}$ Therefore, even under Cardoza-Fonseca's more modest reach, the courts should play a primary role in determining whether a legal distinction exists between "domicile" and "residence." The resolution of this issue inay force the BIA to reconsider its administratively final rule.

\section{Deportation: "A Harsh Measure"}

In addition to the pure question issue, the second reason CardozaFonseca should apply is that important policy considerations are at stake. Cardoza-Fonseca is first an administrative law case and only secondarily an immigration deportation case. However, the Court enunciated its policy concerns regarding the INS' and the BIA's reading of the statute. The Court noted that "[d]eportation is always a harsh ineasure; it is all the more replete with danger when the alien makes a claim that he or she will be subject to death or persecution if forced to return to his or her home country."198 The Court's strong language suggests that deportation does not involve run-of-the-mill agency decisions with purely administrative consequences. Where life and liberty are at stake, the Court may wish to take a harder look at the agency's decisions.

Cardoza-Fonseca accords with the Hearst Publications-Packard Motor Car cases discussed above. Judge (now Justice) Stephen Breyer has explained that where a court confronts important matters of policy, that court is likely to conduct independent, in-depth reviews of agency decisions. ${ }^{199}$ The language in Packard Motor Car indicates that the Court recognized the "tremendously important" policy affecting industry nationwide. ${ }^{200}$ As then Judge Breyer pointed out, Packard "presented a legal question of great importance in the field of labor relations .... [T]t seems unlikely that Congress wished to leave so important and delicate a legal question to the Board to decide."201 Thus, Cardoza-Fonseca is con-

We note at the outset that while the immigration judge . . . couched the question in terms of whether the respondent's 'lawful domicile' came to an end with the immigration judge's May 1975 finding of deportability, the precise legal issue before us is whether the respondent's status as an alien 'lawfully admitted for permanent residence' was then terminated.

Id. at 105 (footnote omitted). Yet in holding that Lok's lawful permanent resident status terminated on July 30, 1976, the BIA leaped to the conclusion that "nor could [Lok's] domicile in this country from then on be considered lawful." Id. at 106 (emphasis added).

In other decisions, the Board clearly distinguished between "domicile" and "residence." See, e.g., In re Anwo, 16 I. \& N. Dec. 293, 298 (BIA 1977) ("[D]omicile is established upon proof of residence, combined with the "intent to make [that residence] a fixed and permanent home." ") (citation omitted).

197. In Lok v. INS, the Second Circuit held that the phrases "lawfully admitted for permanent residence" and "lawful unrelinquished domicile" did not bear the same meaning. 548 F.2d 37, 40 (2d Cir. 1977). The court also indicated that the Board admitted that it was possible for aliens to possess a lawful domicile in this country without being admitted to permanent residence. Id.

198. INS v. Cardoza-Fonseca, 480 U.S. 421,449 (1987).

199. Breyer, supra note 190 , at 397.

200. Packard Motor Car Co. v. NLRB, 330 U.S. 485, 495 (1947) (Douglas, J., dissenting).

201. Breyer, supra note 190, at 371 . 
sistent with the Packard approach wherein the Court is persuaded more by the policy ramifications of the agency's decision than by due deference. ${ }^{202}$

The consequences of an asylum demial are admittedly more severe than the denial of a deportation waiver. Whereas the fear of death and torture often accompanies asylum claims, all deportees do not necessarily face sucl persecution upon deportation. However, as Cardoza-Fonseca recognized, deportation itself is "always a harsh ineasure."203 Here, the BIA's administratively final rule will adversely impact those aliens with significant ties to the Umited States who attain their seventh year of domicile during the pendency of judicial review of their claims. These aliens will lose those faunily, busmess, and property ties formed during tliose seven years. Because of these harsh consequences, reviewing courts should take an independent look at the BIA's rule.

\section{Policy Considerations Suggest Courts Should Not Defer to the INS or BLA in 212(c) Cases}

Cardoza-Fonseca may provide a legal basis for allowing the courts to give the agency's decision less weight during judicial review. Setting aside the Chevron and Cardoza-Fonseca approaches, there are two fundaniental policy rcasons wlyy the courts should not so readily defer to the BIA's statutory interpretation: first, the BIA has little technical expertise to offer to resolve this particular issue, and second, the Agency should not be trusted to decide this issue fairly.

\section{Why Not Defer?}

There are two primary reasons a court should ever defer to an agency's interpretation of the law. ${ }^{204}$ One is that Congress told the courts to defer by delegating to the agency the authority to decide. The other is that the agency should decide because the agency understands the issues better than any other entity. As discussed above, there is little or no evidence suggesting that Congress delegated to the agency the authority to decide the scope of its own discretion. ${ }^{205}$ However, the BIA may argue that it is in a better position to interpret the 212(c) requirements because it is in the busi-

202. Cardoza-Fonseca, sensitive to congressional policy, discussed the prospective impact its holding would have in the asylum area. The Court noted: "In enacting the Refugee Act of 1980 Congress sought to 'give the United States sufficient flexibility to respond to situations involving political or religious dissidents and detainees throughout the world .... Our holding today increases that flexibility ....'" Cardoza-Fonseca, 480 U.S. at 449 (citation omitted).

203. Id.

204. See, e.g., Breyer, supra note 190, at 368-72; Herz, supra note 128, at 194-96.

205. See supra text accompanying notes $166-78$ (discussing the distinction between legislative and interpretive rules). 
ness solely to adjudicate immigration matters and has accumulated much experience in dealing with 212 (c) cases. ${ }^{206}$

The BIA has accumulated wisdom regarding 212(c)'s administrative workings; however, this wisdom is of diminished use when constitutional or common law issues arise. ${ }^{207}$ The courts need not defer to the Agency because the courts are the more informed arbiters of constitutional and common law matters. ${ }^{208}$ The dispute in 212 (c)'s domicile requirement originated when a court cited the Constitution's Equal Protection Clause to extend 212(c) relief to deportees im addition to "excludees." The seven-year cutoff point for domicile purposes would not ordinarily be an issue in exclusion proceedings, because the relief-seeking alien must, by definition, have physically departed from this country. The length of an excludee's domicile would have already been established on the date of departure. Furtliermore, as excludees have no right to judicial review, the issue of accruing domicile during the pendency of judicial review would not arise. Therefore, inherent in this issue is the equal protection question of whether an excludee who has resided in this country for more than seven years inay be treated differently from a deportee who also resided here for more than seven years-a situation that may arise under the BIA's administratively final rule. The BIA is not the proper authority for deciding such constitutional questions. ${ }^{209}$

Resolving this "domicile" issue inay also implicate the common law, on which the courts, not the agency, are particularly expert. Because Congress did not explicitly define "domicile" in the statute, it may be necessary for the courts to look for a generally accepted common law meaning. ${ }^{210}$ The search for domicile's common law meaning (as the Second Circuit has done) involves a thorough search of federal case law. Although

206. The Fourth Circuit aptly put forth the argument that the "administrative agency clothed with responsibility for implementing congressional pronouncements generally is well acquainted with the policy of the statute it administers. This is particularly true when the agency has long been involved in the construction and administration of a given statute or its predecessors." Chiravacharadhikul v. INS, 645 F.2d 248, 250 (4th Cir. 1981) (quoting Baur v. Mathews, 578 F.2d 228, 233 (9th Cir. 1978)). Admittedly, this account applies to the BLA.

207. See Breyer, supra note 190 , at 370 (arguing that courts will defer more when the agency has special expertise that it can bring to bear on the legal question, such as when the issue concerns matters of agency administration rather than common law or constitutional law).

208. See Hi-Craft Clothing Co. v. NLRB, 660 F.2d 910, 914-15 (3d Cir. 1981) ("lf the issue falls outside the area generally entrusted to the agency, and is one in which the courts have a special competence, i.e., the common law or constitutional law, there is little reason for the judiciary to defer to an administrative interpretation.") (citations omitted).

209. The BIA has consistently ruled that it has no power to adjudicate constitutional challenges to the validity of immigration laws. 6I INTERPRETER RELEASES 1053 (1984); see In re Silva, 16 I. \& N. Dec. 26, 31 n.3 (BIA 1970) (Appleman, concurring) ("[The BIA] has no power to declare legislation unconstitutional."). Moreover, the BIA has deferred to the federal courts' constitutional analysis of BIA decisions. See, e.g., In re Silva, 16 I. \& N. Dec. at 29-30 (reversing its decision in light of the Second Circuit's equal protection analysis in Francis, and adopting Francis to cases outside the Second Circuit).

210. See Rosario v. INS, 962 F.2d 220, 223-24 (2d Cir. 1992). 
the BIA may be capable of understanding or even interpreting the common law, the point is that the BIA does not bring to the table its expertise regarding this issue. The courts simply do not need the BIA's help to understand the courts' own common law.

\section{Agency Conflicts of Interest}

In addition to not needing to rely on the BIA's expertise, the courts should not trust either the BIA or the INS to decide this issue properly and fairly. The courts should carefully scrutinize agency decisions in immigration and deportation matters because of the BIA's close links to the INS and the INS' dual service and enforcement missions. In addition, the INS' administrative competence and fairness have often been harshly criticized. ${ }^{211}$

The BIA's interpretations of immigration laws and its administrative reviews of INS decisions may be colored by the BIA's close ties to the INS. Although the BIA functions as an independent check on INS actions, this mdependence may be compromised by the Board's nembers, who are often forner INS employees. ${ }^{212}$ Active Board meinbers also jeopardize their mdependence by engaging in immigration policy-making with Department of Justice immigration officers while adjudicating immigration matters before the BIA. ${ }^{213}$

The BIA's connection with the INS is also probleniatic because the INS is susceptible to popular opimon and political pressure. The INS is in the curious position of serving immigrant clients by granting them the privileges of living $\mathrm{m}$, working in, and becoming citizens of this country, while at the same time enforcing the immigration laws by prosecuting and deporting these very clients. The INS is responsible for facilitating entry, yet preventing unlawful entry, and for granting benefits, yet apprehending and

211. Peter H. Schuck, The Transformation of Immigration Law, 84 CoLUM. L. Rev. 1, 16-17 (1984); see also Kevin R. Johnson, Judicial Acquiescence to the Executive Branch's Pursuit of Foreign Policy and Domestic Agendas in Immigration Matters: The Case of the Haitian Asylum-Seekers, 7 Geo. IMMrG. L.J. 1, 28-33 (1993) (arguing that the Rehnquist Court's deferral of immigration and asylum matters to the INS is misplaced judicial trust).

212. For example, those serving on the BIA when the Lok case was heard included Chairman David Milhollan and Members Louis Maniatis, Fred Vacca, Mary McGuire, and James Morris. See In re Lok, 18 I. \& N. Dec. 101 (BIA 1981) (announcing its administratively final rule). Prior to their BlA appointments, Milhollan and McGuire were formerly employed by the INS, Morris headed the Immigration and Extradition Unit of the Justice Department's Criminal Division, and Vacca served as an attorney for two federal agencies. Johnson, supra note 94 , at 448 n.156.

213. BIA Chairman Milhollan, while chairman, also served on the Alien Border Control Committee, whose objective, among others, was to deport ahen activists who were in violation of the immigration law. See Ronald L. Soble, Official's Dual Role Taints Case Against Aliens, Lawyer Charges, L.A. Times, July 20, 1989, at A3. This Committee also included the director of the Justice Department's Office of Immigration Litigation and representatives of the FBI, CIA, and the State Department's counterterrorism unit. 
removing those ineligible for such benefits. ${ }^{214}$ However, recent trends indicate that the INS has stepped up its enforcement efforts and leveled off its service functions. While the number of lawfully admitted immigrants has dramatically decreased, the number of deportations and required departures has greatly increased. ${ }^{215}$ In light of the political pressures to crack down on illegal immigration, the INS will continue to emphasize its enforcement role, at least in the foreseeable future. ${ }^{216}$ Perhaps this political reality has shaped the INS' mission (whether self-perceived or prescribed by the AG) toward resolving statutory ambiguities against the alien.

The INS' ability to effectively and fairly carry out its mission has also been questioned, if not criticized. As Professor Schuck has explained:

Few areas of public law are so susceptible to administrative abuse and lawlessness as immigration law. The INS is among the inost insular and chronically understaffed of federal agencies .... Aliens, the nominal clients of the system, are politically and economically weak, unfamiliar with legal forms, procedures, and the language, and often reluctant or unable to assert their legal rights. ...

INS decisions, moreover, have low visibility; they occur in isolated adjudicatory contexts in which their larger policy consequences, if any, are fragmented and thus difficult to discern or inonitor. ${ }^{217}$

These allegations raise grave concerns about the propriety of according the INS and the BIA deference. Even though the BIA and the INS are separate entities whereby the BIA polices the INS, one agency's check on another is insufficient to check the abuses which niay inhere in such matters as immigration, deportation, exclusion, and asylum.

Schuck's warning is ominous in light of the INS' and the BIA's track record. Since 1952, the INS and the BIA have routinely adopted the strictest interpretations of the immigration and nationality law. For example, in 212(c) cases, the BIA has held that seven years of domicile can accrue only after the establishment of lawful permanent residence; ${ }^{218}$ that deportees are

214. Office of the Fed. Register Nat'l Archives \& Records Admin., United States GovernMENT MANUAL 1992/1993, at 398-99 (1992).

215. Immigration to the United States dropped nearly $50 \%$ from $1,827,000$ in 1991 down to 974,000 in 1992 . During this same period, the total number of deportations and required departures increased from 1.09 million to 1.14 million. U.S. Dept. OF Justice, 1991 StatisticaI YearBook, supra note 21 , at 156 .

216. See, e.g. Solis, supra note 1, at Al, A7 (indicating that more than 100 immigration-control measures are pending in Congress in 1994). See generally The Unfair Immigration Burden, N.Y. Times, Jan. 11, 1994, at A20 (describing the enormous fiscal burdens of immigration on such states as Califomia, New York, Texas, and Florida). For a discussion on INS vulnerability to domestic political pressures, see Sophie H. Pirie, Comment, The Need for a Codified Definition of "Persecution" in United States Refugee Law, 39 STAN. L. REv. 187, 214-18 (1986); and see also Johnson, supra note 94, at 456-59 (describing immigrants' ineffective political clout to counter popular anti-immigrant sentiment).

217. Schuck, supra note 211 , at $81-82$.

218. In re Lok, 15 I. \& N. Dec. 720, 721 (BIA 1976). 
eligible for relief only for grounds of deportation that had comparable grounds of excludability; ${ }^{219}$ and that domicile may not be accrued during the pendency of federal court appeals. 220

Even when federal courts have decided on 212(c)'s scope and applicability based on constitutional grounds, the INS has not given up the fight to challenge these decisions. To illustrate, take the case of Francis v. INS in which the Second Circuit in 1976 extended 212(c) relief to otherwise qualified deportees for equal protection reasons. ${ }^{221}$ Recall that in In re Silva, the BIA adopted the Second Circuit's decision and extended 212(c) relief to deportees nationwide. ${ }^{222}$ Other circuits subsequently followed Francis. ${ }^{223}$ Despite this settled decision, the INS recently sought to reverse the BIA via administrative action. ${ }^{224}$ The INS urged the AG to reverse Silva and limit the BIA's prior extension of 212(c) to only those seeking a waiver of excludability, and not deportability. ${ }^{225}$ The BIA opposed such a revisitation on this judicially and administratively settled inatter. In 1991, the AG rejected the INS' request, but only on technical grounds. ${ }^{226}$

219. In re Wadud, 19 I. \& N. Dec. 182, 184 (BIA 1984). The BIA did reverse itself, discarding the requirement that in order to be ehigible for 212(c) deportation relief there had to be an analogous ground of inadmissibility. In re Hernandez-Casillas, Interim Dec. 3147, at 5 (BIA 1990). See 67 INTERPRBTER Releases 224 (1990) (digesting the BIA's decision in In re Hernandez). However, the AG overruled the Board's decision. In re Hernandez-Casillas, Interim Dee. 3147, at 27 (AG 1991).

220. In re Lok, 18 I. \& N. Dec. 101, 105-06 (BIA 198I).

221. See text accompanying notes $9-10$.

222. In re Silva, 16 I. \& N. Dec. 26, 30 (BIA 1976).

223. See Tapia-Acuna v. INS, 640 F.2d 223, 224-25 (9th Cir. 1981); Byus-Narvaez v. INS, 601 F.2d 879, 881 (5th Cir. 1979); Vissian v. INS, 548 F.2d 325, 328 n.3 (10th Cir. 1977).

224. In a 1990 memorandum to Attorney General Dick Thornburgh, the BIA Chairman clearly noted that Francis' 212(c) extension is a settled result. See 67 INTERPRETER Releases 480-81 (1990) (reprinting BIA Chairman David L. Milhollan's memorandum to Dick Thornburgh, Attomey General) ("It would seem difficult, however, for the Government to disassociate itself from this result at this point. If seetion 212 (c) is to be revisited (particularly to the extent now urged by the Service), a better approach may be through legislative action in view of the long-standing administrative and judicial interpretations of section 212 (c) .... .'); see also Hno \& CRUHLAC, supra note 36, at 1-2.

225. See 67 INTERPRETER ReleAses 354-55 (1990) (reporting INS Commissioner Gene McNary's "radical," if not "rash" request to the AG to overrule Silva).

226. In re Hernandez-Casillas, Interim Dec. 3147, at 36 (AG 1991). The AG's March 1991 decision gave two reasons for rejecting the INS' request: the INS did not challenge Silva's validity before the BIA and reexamining the Silva issue was not neeessary to decide the present case.

Despite the AG's established practice of equating a deportee's with an excludee's applieation for 212(c) relief, the BIA's Silva decision, and the federal appellate eourt's Francis ruling, it seems that the INS was ultimately convinced that 212 (c) applied to deportation procecdings only after Congress explicitly included 212 (c) under its "deportation procedures" provision. 56 Fed. Reg. 50,033 (1990). In an October 1991 notice publication the INS noted that "Congress exphicitly rceognized the applicability of section 212 (c) relief to deportation proceedings when it added section $242 \mathrm{~B}(\mathrm{e})(5)$ to the Act." Id. Section 242B(e)(5) included 212(c) as one of the types of relief covered under deportation procedures. Immigration Act of 1990, Pub. L. No. 101-649, 104 Stat. 4978, 5065 (1990). Howevcr, in the Immigration Technical Corrections Act of 1991 amending the 1990 Act, Congress removed 2I2(c) relief from its "deportation procedures" section. Pub. L. No. 102-232, § 306(c)(6)(J); 8 U.S.C. § 1252b(e)(5) (Supp. V 1993). Although Congress did not also amend section 212(c) to make 212(c) explicitly inapplicable to deportations, the INS might seize this technieal correction as an opening to reversing the BIA's Silva decision. 
While the BIA prevailed over the INS in this instance, the INS' aggressive posture suggests the danger in entrusting the INS, the BIA, or the AG with too inuch authority regarding 212(c)'s eligibility requirements. If the INS could limit 212(c) eligibility by interpreting the requirements strictly, then it would also effectively decide for itself when not to evaluate the merits of an alien's case. The INS could keep out certain aliens, like George Variamparambil, from 212(c) consideration without violating the letter of the Agency's obligation to hear the alien's case. ${ }^{227}$ Moreover, any trust (expressed in the form of deference) the courts have in the BIA to uphold 212(c) is worth only as much as the AG, the BIA's administrative overlord, wishes. And finally, if courts defer to the AG, then the courts risk having this deference flow into the hands of the INS and BIA, to which the AG has already delegated her authority in immigration matters.

This Part has shown how Chevron has created a trap of agency deference, from which 212(c) cases have difficulty escaping. However, the courts can, through such judicial approaches as in Cardoza-Fonseca, and should, for policy reasons, unfetter themselves from agency deference. Interpreting the 212(c) domicile requirement is a function the courts should perform. Part IV offers one possible interpretation of 212(c) that is better than the BIA's administratively final construction.

IV

\section{A Judiclally Final Rule}

Part II of this comment argued that the BIA's administratively final rule violates Congress' spirit, if not purpose, in providing section 212(c) relief. Part III analyzed the Chevron "trap" which led many appellate courts to defer to the agency's 212(c) interpretations. However, CardozaFonseca's approach provides a legal means through which the courts can set aside agency deference; deportation's harsh consequences and the INS' and BIA's conflicting missions are policy reasons why the courts should interpret 212(c) on their own. This Part suggests one viable and practical interpretation.

The courts should adopt a rule that allows aliens to accrue 212(c) domicile time until their deportation orders becoine judicially final or until the expiration of the ninety-day allotted time to file for judicial review. ${ }^{228} \mathrm{~A}$ deportation order becomes judicially final when a federal appeals court denies the alien's petition to reverse the BIA/INS order of deportation.

227. If, instead, the INS had found Mr. Variamparambil eligible for 212(c) relief, then the INS would have had to hear the merits of his case. Whether the INS grants Mr. Variamparambil a waiver is in the INS' discretion, subject to the Marin factors which the BIA has outlined. See In re Marin, 16 I. \& N. Dec. 581, 583-85 (BIA 1978) ("[T] he Attorney General or his delegate is required to determine as a matter of discretion whether an applicant warrants the rehef sought.").

228. This is similar to one of the possible domicile cutoff points that the BIA considered in Lok. See supra note 179. 
Once a federal appeals court unfavorably acts on the alien's case, the deportation order will be deemed judicially final.

This judicially final rule does not suffer from the infirmities associated with the administratively final rule. The primary difference between thcse two rules is that the judicially final rule places the domicile termination point outside the hands of the BIA. The judicially final rule is also a better choice because it accords with other extra-212(c) statutory rights and obligations which Congress bestowed and imposed on resident aliens. Chief among these are Social Security benefits and imcome tax obligations. If the judicially final rule is accepted, then the termination of 212(c) doimicile would better fit into the statutory tax and welfare schemes. This coordination would eliminate the imcongruous result of a United States taxpaying resident alien, receiving welfare benefits, yet not being allowed to receive do1micile credit for 212 (c) purposes.

\section{A. A Judicially Final Rule: Fair and Humane}

A switch to the judicially final rule would solve many of the administratively final rule's shortcoimings discussed in Part II. The judicially final approach satisfies 212(c)'s purpose to cabm the AG's discretion, while upholding 212(c)'s humane and lenient spirit. This approach also allows aliens to exercise their right to judicial review of agency decision without loss of doimicile time. This rule is at the same tinie a measured response because it does not extend indefinitely the period of tine during which an alien may accrue seven years of doumcile. Each of these points will be discussed in turn.

First, a judicially final rule would remove the danger of giving the agency too much control over when it may exercise its 212(c) discretionary power. Under the admimistratively final rule, the BIA's timing of its final deportation order effectively disables, or in some cases enables, certain aliens from meeting 212(c)'s threshold eligibihty requirements. ${ }^{229}$ The BIA's control, albeit partial, over 212(c)'s eligibility requirements enablcs the Board both to accord $212(\mathrm{c})$ relief to an otherwise meligible alicn and to deny outright consideration to an alien otherwise eligible for relief. ${ }^{230}$ In contrast to the current rule, the proposed rule fixes an alien's domicile termination independent from agency action. Establishing domicile's end relative to federal court action removes conflicts of interest and greatly reduces the opportunity for the BIA to meddle with 212(c)'s eligibility requirements.

229. See text accompanying notes $90-91$.

230. Two undesirable scenarios may arise under the administratively final rule. One occurs when the BLA delays its final decision by sevcral days, finds the alien eligible for 212(c) relief, and reverses the IJ's denial of discretionary relief. This decision would give an otherwise ineligible alien $212(\mathrm{c})$ relief. The second arises when the BIA issues a quick decision upholding the IJ's deportation order, cuts off domicile accrual time, and then finds the alien ineligible for $212(\mathrm{c})$ relief. This result denics a potentially eligible alien from even being considered for 212 (c) relief. 
Second, the judicially final rule is more in keeping with 212(c)'s underlying humane intent. This proposed approach tends towards leniency by allowing aliens to exhaust both their administrative and judicial reinedies before they lose their right to accrue domicile time. This rule would also be less confusing to aliens than the administratively final rule. As one court has indicated, what is administratively final for certain administrative purposes is not final for all purposes. ${ }^{231}$ This confusion arises from the complex administrative layers consisting of the INS, the BIA, and the Department of Justice, respectively headed by a Commissioner, a Chairman, and the AG, and staffed by district directors, IJs, and board members. For example, is the BIA's affirmation of the INS's deportation order truly administratively final where the AG may overrule the BIA's decision? The judicially final approach avoids this bureaucratic confusion: once a federal court judge acts on an alien's deportation order, the order becomes judicially final. 232

Third, Congress explicitly gave aliens the right to judicial review. ${ }^{233}$ Aliens slrould suffer no prejudice, imcluding termination of domicile, while exercising their statutory rights in this country. A judicially final rule allows aliens to accrue domicile time until a federal court acts on their petition, if they chose to file one. This rule is fair because if the alien leaves this country while an appeal is pending in the court of appeals, the petition for judicial review is deemed withdrawn. ${ }^{234}$ Furthermore, this approacl is consistent with the BIA's own notion of domicile. The BIA contends that domicile requires residency in the United States with the intent to make the United States honie for the indefinite future. ${ }^{235}$ Seeking judicial review to overturn a deportation order demonstrates the alien's strong desire to renrain $\mathrm{m}$ the United States. And if the alien, meanwhile, also petitions the Agency for 212(c) relief, this shows that the alien believes he or slie has the requisite ties to this country to convince the agency that the United States is "home."

Finally, the judicially final rule does not go overboard. It is a practical approacli that allows the alien to have his or her day in federal court witliout losing domicile status before the case is even heard by a federal court

231. Butros v. INS, 990 F.2d 1142, 1145 (9th Cir. 1993).

232. Federal appellate court action defines "judicially final" for 212(c) domicile purposes. Although the United States Supreme Court is the court of last resort, the Court need not hear these aliens' appeals. Of course the alien need not seek appellate court judicial review, in which case the ahen voluntarily terminates domicile.

233. See supra note 114 .

234. 8 U.S.C. $\S 1105 a$ (c) (1988). But see Zepeda-Melendez v. INS, 741 F.2d 285, 287-88 (9th Cir. 1984) (holding that an alien who left because of an unlawful deportation order still quahifies for appellate review).

235. In re Sanchez, 17 I. \& N. Dec. 218, 221 (BIA 1980) ("T]n order for an alien to establish 'domicile' in the United States, he must be physically present here and have the intention of making the United States his home for the indefinite future.'); see also In re Anwo, 16 1. \& N. Dec. 293, 298 (BIA 1977). 
judge. ${ }^{236}$ This rule would not allow the ahen to skirt the domicile rule by filing endless appeals, because once the federal court has acted on the first appeal, the deportation order would be deemed final. If an alien decided to file frivolous appeals after an appellate court ruling, then the alien remains in this country as a matter of grace and not of right. The alien has already exercised the right to judicial review and the automatic deportation stay is lifted. The judicially final rule thus rightfully denies aliens domicile credit for remaining in the United States after a federal judge has affirmed their deportation orders.

\section{B. Section 212(c) and Alien Entitlements/Obligations}

A judicially final reading of 212(c) is also consistent with Congress' treatment of resident aliens outside the immigration and deportation context. Consider, for exaniple, Social Security entitlements and tax obligations. Whereas domicile for 212(c) purposes is terminated upon the BIA's administratively final order, Social Security payments and income tax liabilities may still continue well after the BIA's order. The judicially final approach, however, terminates domicile closer in time to when welfare benefits cease and the tax burden is lifted. Although there is no constitutional reason that "who stays" should coincide with "who pays," fundaniental fairness suggests that if aliens pay income taxes $m$ their capacity as permanent residents, they should continue receiving rights and benefits, including the analogous benefit of accrumg domicile credit.

\section{Income Taxes}

Reading section 212(c) in conjunction with the Internal Revenue Code and Federal Tax Regulations lends support to the fairness argument. A judicially final rule is consistent with the Revenue Code's wording and would not prejudice aliens pursuing 212 (c) relief.

The tax regulations nake all resident aliens liable for inconie taxes imposed by the Code, whether the incoine is received fronl sources within or outside the United States. ${ }^{237}$ The Code defines "resident aliens" as those who had been lawfully admitted for permanent residence or who meet the "substantial presence test."238 Only if permanent residence status is administratively or judicially revoked, or determined to have been abandoned, can

236. If an alien chooses not to seek judicial review, then the judicially final rule extends the domicile accrual period by only 90 days. In the Immigration Act of 1990 , Congress reduced to ninety days, from six months, the time allotted to the alien to appeal an administratively final deportation order. 8 U.S.C $\S 1105 a(a)(1)$ (Supp. V 1993).

237. I.R.C. $\$ 1.1-1$ (b) (West I993).

238. Id. $\$ 770 \mathrm{I}(\mathrm{b})(1)(\mathrm{A})$. The "resident alien" definition also includes a third possibility that the individual meets certain requirements and elects to be treated as a resident for a given tax year. See $\S 7701$ (b)(l)(A)(ïi). 
resident aliens avoid taxation under the Code. ${ }^{239}$ Thus, the Revenue Code considers either an administrative or judicial revocation sufficient to relieve resident ahens of their tax liability.

A judicially final rule would alleviate the Catch-22 situation created under the administratively final rule when an alien petitions for 212(c) after the Board has acted on the deportation order. If aliens in this situation cease to pay taxes by rightfully claiming an administrative revocation of permanent residence status, they liurt their cliances of successfully obtaining 212(c) relief. While paying taxes does not guarantee 212(c) relief, not paying taxes is devastating to the aliens' case. Oftentimes IJs will cite the alien's nonpayment of taxes as a negative factor against granting relief. ${ }^{240}$ Thus, even though the tax laws relieve aliens of their tax obligation upon administrative revocation of residence status, aliens pursuing 212(c) relief find it necessary to continue paying their taxes. But if these aliens continue filing tax returns, they voluntarily do so without the concomitant benefit of receiving domicile credit. Therein lies the "catch."

A judicially final rule solves this dilemma. The alien would lrave but one clear strategy: continue to pay taxes and accrue 212(c) domicile time until a federal court acts upon the alien's deportation petition. Without suffering the loss of domicile time, the alien has added incentive to pay taxes, and the government can enhance its revenues.

\section{Social Security}

In the same way that Social Security entitlements continue beyond the BIA's final deportation order, so should domicile credit. Social Security old-age and disability insurance is available to any qualifying alien, regardless of residency status. ${ }^{241}$ These insurance benefits terminate only after an alien recipient has been deported. Monthly benefits cease in the montl following that in which the AG notifies the Secretary of Health and Hunnan Services that such alien was deported. ${ }^{242}$ However, deportation is not determined as of the BIA's administratively final deportation order. Deportation is determined by the physical act of deportation, rather than any

239. Id. § 7701(b)(6); see Robert L. Dumont, Defining "Resident Alien" for Tax Purposes Under the Deficit Reduction Act of 1984, 3 ImMagr. L. Rep. 81, 83 (1984) (describing the tax laws' extended reach over all resident aliens).

240. See, e.g., Arango-Aradondo v. INS, 13 F.3d 610, 613 (2d Cir. 1994) ("[I]t is evident that the immigration judge carefully and thoroughly weighed the evidence in Arango's favor . . . against the detrimental evidence (including . . . his failure to file taxes . . .)."); see also Roger C. Wolf, $A$ Practitioner's Guide to 212(c) Waiver Cases, 9 ImMIGr. J. I, I4 (1986) ('Many judgès require submission of federal income tax returns to prove the seven year residence. Failure to have filed tax returns can be ground for denial of relief.").

241. See 42 U.S.C. $\S \S 402$ (a), 414(a) (1988); see also CARINER ET AL., supra note 7, at 158 (describing which government benefits are available for aliens).

242. 42 U.S.C. $\S 402(n)(1)(A)$ (1988 \& Supp. V 1993). 
administrative action. ${ }^{243}$ Under this deportation definition, an alien is deported only after physical departure-after administrative and judicial remedies have been exhausted or waived. A judicially final rule likewise would not bar domicile accrual until the BIA and the federal courts have acted.

Critics may argue that Social Security benefits and domicile credit are very different im nature and thus need not be correlated. For example, Social Security payments are legally recognized property rights representing inonetary returns on an individual's vested interest; domicile credit is not. Whereas the Supreme Court has accorded due process protection to entitlements and even welfare benefits, domicile credit is not so protected because it is not a property right. ${ }^{244}$ However, significant property interests attach to one's ability to accrue domicile time. ${ }^{245}$ It is undemable that aliens who lose the abihty to accrue domicile under the administratively final rule may lose their jobs in the Umited States and be separated froin their business, economic, and property ties in this country. The judicially final rule does not accord new rights where none previously existed; it does recognize that hasty administrative action should neither jeopardize significant property interests nor destroy precious family ties.

\section{CONCLUSION}

The federal courts should revisit the issue of lawful doinicile under section 212(c) of the Immigration and Nationality Act. Without judicial intervention, the BIA's administratively final rule will continue to create hardships not only for those deported aliens who have reformed their ways

243. No old-age or disability insurance benefit is payable to the individual for any month occurring after the month in which the AG notifies the Social Security Administration ("SSA") (on behalf of the Secretary of Health and Human Services) that such person was deported. 20 C.F.R. $\S 404.464$ (1993). According to the SSA's Program Operations Manual System, the SSA determines dcportation according to INS Form I-157, Notice of Deportation. The INS notifies the SSA of deportation by sending the SSA Form I-157 which gives the reason for deportation and the date the ahen left the country. See Marcello v. Bowen, 803 F.2d 851, 855-56 (5th Cir. 1986) (citation omitted) (describing the proccdures under which the SSA determines deportation).

244. See Goldberg v. Kelly, 397 U.S. $254,261-62$ \& n.8 (1970) (treating government welfare entitlements as property for due process purposes). The Court subsequently introduced a new balancing approach to due process analysis in Mathews v. Eldridge, 424 U.S. 319, 335 (1976). See JERRY L. Mashaw, Due Process in the Admmistrative State 102-03 (1985).

245. Considering the individual's property interests at stake in the administrative setting may be appropriate given the United States Supreme Court's three-factor balancing approach in Mathews v. Eldridge, 424 U.S. 319,335 (1976). To decide what proccss was due in administrative procedures affecting property interests, the Court in Mathews considered, first, the private interest affected by state action; second, the risk that such action would erroneously deprive one of such interest and the value of creating additional procedural safeguards; and third, the state's interest. Id. at 335 . In the 212(c) context, aliens under a deportation order risk the loss of jobs or businesses in this country. A judicially final rule would insure independent court review of the ahen's deportation status prior to any change in his or her domicile status. This judicially final rule weighs favorably against the government's diminished interest in an administratively final rule, where a federal statute has already conferred to aliens the right to judicial review. 
and built livelihoods in this country, but also for American citizens whose family members are deported.

Congress imtended 212(c) waivers to temper the harsil effects that deportation and exclusion have on deserving aliens entangled in our complex and often rigid immigration laws. Unfortunately, the BIA and the INS, who interpret and apply this humanitarian provision, face political and institutional pressures to enforce the deportation and border control aspects of the immigration laws more strictly.

Despite these agency conflicts of interest, nnany courts, wishing to remain safely within the himits of their judicial authority, cite to Chevron's principle of agency deference in upholding the BIA's strict interpretations of section 212(c). Chevron, however, does not clearly instruct the courts when, or perhaps even how, to apply its test of agency deference. Section 212(c)'s lawful domicile issue raises some doubts over whether Chevron provides an effective framework for analyzing all types of agency actions.

For example, does Chevron apply when an agency has expanded the statute's scope, making it nearly impossible for Congress to have "directly spoken" on this issue? Should Chevron apply to the second part of a twopart statute, where one part gives the agency broad discretion, but the second cabins this discretion? ${ }^{246}$ Alternatively put, does it make sense to use Chevron to evaluate an agency's interpretation of the scope of its own authority? Fimally, is Chevron an appropriate standard of review in deportation cases, where the individual stakes are so high?

Chevron may be good law generally, for it affirms Congress' delegation of authority to administrative agencies. But courts should not be unduly constrained by Chevron's shackles, for the Umited States Supreine Court in Cardoza-Fonseca also reminds the courts that the judiciary's duty to interpret statutes may, in certain instances, override agency deference. Interpreting section 212(c)'s domicile requirement may be such an instance. ${ }^{247}$ So before reviewing courts march down Chevron's path in 212(c) and other cases, they should more critically determine whether Chevron applies, and if it applies, more carefully apply Chevron's two-step analysis.

246. See supra text accompanying notes $176-78$.

247. The Second Circuit, for example, in overturning one of the BIA's 212(c) lawful domicile interpretations balanced agency deference against the court's "heavy responsibility to set aside administrative decisions that are inconsistent with a statutory mandate." Lok v. INS, 548 F.2d 37, 38 (2d Cir. 1977). The court described its statutory duty as follows:

We have had occasion to note the striking resemblance between some of the laws we are called upon to interpret and King Minos's labyrinth in ancient Crete. The Tax Laws and the Immigration and Nationality Acts are examples we have cited of Congress's ingenuity in passing statutes certain to accelerate the aging process of judges. ... The fate of the alien faced with imminent deportation often hinges upon narrow issues of statutory interpretation.... Emboldened by Thesean courage and fortified by a close examination of the statutory language, we believe that the Board of Immigration appeals erred in denying the petitioner relief on the ground that it did....

Id. at 38. 
Courts would be wise to consider that all agency actions are not alike. Unlike rate-making decisions or administratively created "bubble" rules, deportation proceedings can drastically impact those who risk losing their families, jobs, and economic ties to this country. These aliens, after all, stand to lose "all that makes life worth living."248

248. Ng Fung Ho v. White, 259 U.S. 276, 284 (1922) ("To deport one ... may result also in loss of both property and life; or all that makes life worth living."). 